\title{
The Impact of the Common Vole on the Vegetation of Agroecosystems
}

\author{
Janusz TRUSZKOWSKI
}

Truszkowski J., 1982: The impact of the common vole on the vegetation
of agroecosystems. Acta theriol., 27, 23: 305-345 [With 22 Tables \& 6 Figs.]

An estimate was made of the effect of a population of the common vole Microtus arvalis (Pallas, 1779) on the crop production of a group of cultivated fields in an area forming 3100 ha of typical agricultural land in the Wielkopolska region of Poland, analysis variations in population density of this species, the composition of its food, the capacity for regeneration of different species of plant and the proportion consumed from the whole biomass of eliminated plants. It was found that the vole is able to reach considerable density in about only $19 \%$ of the study area (lucerne, meadows, fringes of shelterbelts), in about $48 \%$ occurs regulary but not very numerously (chiefly in cereal crops) and usually does not occupy $23 \%$ of the region (root crops, maize, wooded land). It occupies lucerne crops in the greatest numbers, since $74 \%$ of all voles present in cultivated fields live in lucerne, which forms $8.5 \%$ of the whole of the area. During the year, depending on the phase in the cycle of variations in numbers, voles remove from 1.6 to $45.8 \%$ of the biomass of primary production from an average hectare of lucerne. This species is not of economic importance in other crops, since on an average it eliminates about $1 \%$ of primary production (winter cereals, rape), or $0.1 \%$ (spring cereals). In the study area the vole population eliminated from 0.2 to $6.4 \%$ of primary production from an average hectare of cultivated crop. The animals were found to show preference for feeding on weeds in a cultivated area. The effect of the common vole on the crop yield of cultivated plants depends on its density and to a great extent the duration of its effect on a plant, but to a lesser degree on the amount itself of biomass eliminated. Damage is chiefly caused by the voles feeding on lucerne in summer and autumn, on cereals in late spring and summer, and on rape from autumn to late spring. At other times there is strong regrowth of plants, which compensates to a great degree for the losses caused by nibbling rodents. The estimates obtained for amount of damage caused by the vole in crops in relation to income from plant production on the local State Farms are from 0.5 to $16 \%$ (in average years $3.5 \%$ ). In this value as much as $97 \%$ of losses are due to the vole population's activities in lucerne crops.

[Dept. of Agrobiology and Forestry, PAS, Swierczewskiego 19, 60-809 Poznań, Poland]

\section{INTRODUCTION}

The common vole, Microtus arvalis (Pallas, 1779) is a small rodent occurring widely over Europe and Asia. It is the most numerous mammal in Poland, and particularly great densities are reached in the western 
and southern parts of Poland (Skuratowicz, 1961 ; Caboń-Raczyńska \& Ruprecht, 1977; Adamczewska-Andrzejewska, 1974). Mass irruptions occur roughly every 3-4 years (Elton, 1942 ; Skuratowicz, 1957 ; Migula et al., 1970), and during these periods it becomes an economically important pest species. The greatest losses are caused in lucerne crops, in which it occurs most numerously (Kratochvil, 1959 ; Bashenina, 1962 ; Ryszkowski, Goszczyński \& Truszkowski, 1973 ; Ryszkowski \& Myllymäki, 1975).

A large number of monographs have been devoted to this species on account of its ecological and economical importance (Kratochvil, 1959; Bashenina, 1962 ; Straka, 1967), but even so there still remain many problems not so far investigated. Considerable progress in obtaining knowledge of the rodent's bioenergetics was not made until the period of International Biological Programme, when the daily energy budget was calculated for the vole (Trojan \&Wojciechowska, 1969 ; Grodziński et al., 1977) and an estimate made of many detailed bioenergetic data (Drożdż, 1968 ; Migula 1969 ; Drożdż, Górecki \& Sawicka-Kapusta, 1972 ; Sawicka-Kapusta et al., 1975). Detailed knowledge of the amount of food they consume was of greatest importance to estimates of the role small rodents play in ecosystems. During this period several studies were made in which the rodents' consumption was compared with the amount of food supply available to them. The most complete presentation of the results of these estimates for ecosystems of the temperate zone is to be found in the study by Golley, Ryszkowski \& Sokur (1975). The degree to which many rodent species make use of food supply is low, often negligible (below $1 \%$ ), which would appear to point to the unimportant role of these animals in the functioning of settled ecosystems. It was found at the same time that the vole is capable of causing great losses both in given crops (Ruzič, 1967, 1971; Tertil, 1974) and on the scale of whole regions or countries (Grulich, 1959 ; Bashenina, 1962 ; Sokur, 1963). When these groups of results were compared the role of extraenergetic effects of the activities of small mammals became clear (Tahon, 1969) and led to a wider view on the complex relations between animalecosystem (Golley et al., 1975 ; Ryszkowski, 1975) and attempts at obtaining information on the mechanism of these relations (Ryszkowski, Goszczyński \& Truszkowski, 1973 ; Tertil, 1977; Babińska-Werka, 1979).

The purpose of the study was to attempt to estimate the action of a population of common voles on vegetation of a typical agro-ecosystem in the intensively cultivated agricultural Wielkopolska region of Poland. The studies were carried out in an area of over 3000 ha, in all the main crops of a group of arable land. The density of the vole population was estimated over a full cycle of several years of variations in its numbers. Particular attention was given to its action apart from consumption. 
Analysis was made of the composition of its diet in the main crops, and estimates of its effect on a change in the crop yield due to nibbling plants, the regenerative capacity of plants, the ratio of consumption value to biomass of plants excluded from further production but not consumed by these animals. Using analyses of agricultural estimates of crops, data on crop structure, the economics of farms and development trends in agriculture as a basis, an attempt was made at estimating the current economic significance of the vole and the prospects of its occurrence with continuing intensification of agricultural management.

The majority of the data used in this study were obtained during the period from 1971-1976.

\section{STUDY AREA}

Studies were carried out in the immediate vicinity of Turew $\left(50^{\circ} 04^{\prime} \mathrm{N} ; 16^{\circ} 48^{\prime} \mathrm{E}\right)$ over an area of about 3100 ha, with supplementary observations in neighbouring areas. This region is considered as part of what is known as the Kościan Plain and lies at an average altitude of $80 \mathrm{~m}$ above sea level. It is characterized by a warm climate, with hot summer and low rainfall. Continental features are strongly marked (Madany et al., 1972a, b). The majority of the soils are light, sandy-clay lying on light boulder-clays (Margowski, 1972).

The typical plain agricultural landscape is predominant, with few trees (about $13 \%$ of the area). There are characteristic and numerous shelterbelts of various types and size, the first of which were planted in this area during the first half of the 19th century. Cultivated land occupies about $80 \%$ of the area, and buildings, roads and bodies of water about $8 \%$ (Table 1 ).

\section{Table 1}

Spatial structure of biotopes during the growing season (after Ryszkowski et al., 1973, changed).

\begin{tabular}{lrr}
\hline \multicolumn{1}{c}{ Type of biotope } & Area in ha & Per cent \\
\hline & & \\
Woods and shelterbelts & 392.9 & 12.8 \\
Meadows, pastures & 317.8 & 10.2 \\
Lucerne & 182.7 & 5.9 \\
Winter rape & 64.5 & 2.1 \\
Winter cereal & 746.0 & 24.1 \\
Spring crops (cereals, vetch, pea, saradella, & & \\
lupin etc.) & 543.8 & 17.5 \\
Root crops and maize & 612.3 & 19.7 \\
Non-arable land (roads, buildings, ponds, canals) & 241.0 & 7.7 \\
Whole study area & 3100.0 & 100.0 \\
\hline
\end{tabular}

Within the study area (3100 ha) there were 2150 ha of arable land on which approx. 25 species of the more important crops were grown. The largest area $(37.7 \%)$ is occupied by winter crops: cereals and rape, perennial crops $8.5 \%$, spring crops $25.3 \%$, root crops and maize $28.5 \%$. There were no distinct changes in the structure of crops during the study period (1971-1975), only a gradual tendency 
being observed to replace rye by barley, which gives larger crop yield, and also partly by sugar beet and rape. In 1974 a new winter crop began to be cultivated (a cross between fodder cabbage and rape) given the name perko.

Agricultural management is intensive in this region and is distinguished by a higher degree of mechanization of agrotechnical work, considerable use of artificial fertilizers (almost $20 \%$ more than the national average) and pesticides. Very large-scale fields, from $30-60$ ha in extent, of the State Farms and Production Co-operatives occupy $74 \%$ of the total area of arable land.

The character of the landscape (numerous shelterbelts) is favourable to maintenance in the study area of a strong group of predatory birds and mammals, which in certain periods exert great pressure on the vole population (Ryszkowski et al., 1973).

\section{METHODS FOR MAKING ESTIMATES}

\subsection{Densities and Spatial Structure}

One of the chief purposes of this study was to obtain absolute estimates of the numbers of the vole population in the large study area, hence it was essential to ensure that a fully representative number of crops was included in estimates within the relatively short periods of quantitative sampling.

The method used consisted in capture from selected areas of the animals which had been flushed out from their burrows by pouring water into them. This made it possible, unlike the methods based on trapping rodents in different types of trap, to obtain far more quickly quantitative estimates close to absolute estimates. This method has been given in greater detail in the paper by Ryszkowski et al. (1973).

Estimates of the density of voles were made by this method three times a year: in spring (April, May), summer (July, August) and autumn (October, November). A single sample consisted of the number of rodents caught from an area of $625 \mathrm{~m}^{2}(25 \times 25 \mathrm{~m})$. In fields with perennial crops (lucerne) 5 samples were taken at random from each field and 10 samples from fields of the remaining crops. Observations of recaptures of previously marked animals and multiple captures from the same area made it possible to establish that a certain number of voles failed to be caught during trapping (by their remaining in burrows, escaping etc.) and therefore an estimate of numbers reduced by a certain percentage was obtained. In lucerne and rape crops this was $25 \%$, and in cereal crops $7 \%$. Results of field estimates were increased by this value in further calculations.

As early as the Initial part of the study period it was found possible to distinguish groups of crops in which density of voles was similar (differences were not statistically significant). This greatly simplified work, as it made it possible to choose crops characteristic of the given group, and estimates were made chiefly on them. The results obtained were referred to the whole area occupied by the given type of crop. Rye was taken as a crop typical of winter cereals, oats for the group of spring plants (wheat, pea etc.), lucerne as perennial crop. Rape crops formed a separate question. Root crops (potatoes, beet) and maize were characterized by zero or nearly zero head of voles, hence only control approximate estimates were made on them in subsequent years.

On an average the study area included 7 lucerne fields, 6 rape fields and 25-40 fields of the remaining crops, chiefly cereals (these figures apply only to large-scale fields on state and co-operative farms). Before starting out on quanti- 
tative estimates approximate estimates were made of the head of voles (number and size of active colonies) in all the fields of the given crop. By distinguishing fields with anticipated high, medium and low density of voles it was possible to carry out the estimate in selected fields proportionately to the percentage of the three classes of density found for the whole area of the given crop. In this way it proved possible to avoid distortion of results by fortuitous estimates from fields with maximum density of voles only. Trapping was carried out in each series (spring, summer, autumn) on over $50 \%$ of the lucerne and rape fields situated within the study area and $25-40 \%$ of fields with other crops.

The number of voles occurring during a given period in a given crop was estimated from corresponding estimates of average density and the size of the area occupied by this crop.

Estimated of the total number of individuals present in the study area in different years were obtained by calculating so-called individual-days (Ryszkowski \& Petrusewicz, 1967) and dividing this value by the accepted average length of life of voles. The values of the accepted assumptions and parameters are presented jointly in the following section of this paper.

During the five-year period of these studies - 1971-1975 - estimates were made of the density of voles on almost 550 fields of different crops. During the course of fifteen trapping series on selected fields rodents were caught from 880 areas and a total of 5420 common voles obtained.

\subsection{State of Biomass and Composition of Vegetation}

Estimates of plant biomass were made in connection with the studies carried out on the composition of the common vole's diet in cultivated fields and the regenerative capacity of the plants it nibbles. Use was also made of agricultural estimates of crops from fields situated in the study area, obtained from the managers of State Farms and Plant Breeding Stations.

Samples were taken during characteristic periods connected with the phenology of cultivated plants or the way man makes use of them. In winter cereals and rape samples were taken four times over the period of their vegetation cycle: during the plant resting phase (winter), after plants begin growth (April), during the period cereals form ears or rape flowers (April-May) and during harvesting. In the case of spring cereals it was possible to take samples only during the last two phases, sampling lucerne during successive mowings, usually in May, July and August, and in addition before plants began growing and in autumn when regrowth of plants was slow.

The way in which samples were taken and their size and number, depended on the character of the estimates of the effect of the vole's activities. Plant biomass during the given period was assessed on the basis of 15 plant samples $0.25 \mathrm{~m}^{2}$ in size $(50 \times 50 \mathrm{~cm})$ or 50 samples $314 \mathrm{~cm}^{2}$ in area chosen at random from the given field of the chosen crop, using a metal frame or hoop $10 \mathrm{~cm}$ in radius. The harvesting method was used for estimating biomass. The plants were cut from defined areas at a height of $0.5 \mathrm{~cm}$ above ground level. Material from the sample in the fresh state was segregated into its various elements: cultivated plants, monocotyledenous and dicotyledenous weeds. The plants were next dried to constant air-dry biomass at a temperature of $85^{\circ} \mathrm{C}$ and weighed with accuracy to $0.1 \mathrm{~g}$. From 1973-1975 a total of 1720 plant samples were taken from barley, oats, winter wheat, rye, rape and lucerne crops. 


\subsection{Composition of the Vole's Diet}

The composition of the vole's diet and its variations depending on the development phase of plants, were defined by means of analysis of stomach contents of animals caught in basic crops characteristic of the occurrence of this species, that is lucerne, rye and rape. The trapping times for parties of animals were synchronized with the development phases of cultivated plants. Trapping of voles and estimates of the state and structure of plants were carried out simultaneously, over the same period on the same areas of selected fields. In order to limit the side-effects of other crops, shelterbelts etc. large-scale fields were chosen and estimates made in the parts of the fields at a distance from the edge. A total of 646 vole stomachs containing varying quantities of food were used for analysis. The most numerous material was obtained from lucerne ( $46 \%$ of stomachs), $33 \%$ from a rye crop and $21 \%$ from rape. The majority of the voles were caught by means of flooding their burrows with water. After rye and rape grew tall (May, June), the animals were obtained from snap traps set in these crops.

Stomach contents not analyzed on the day the given animals were caught, were conserved by means of drying them on pieces of cardboard. Microscopic analysis of stomach contents was made by means of the method, the principles of which were described by Holišova (1966). The technical instructions contained in papers by Górecki \& Gębczyńska (1962), Zemanek (1972), Gębczyńska (1976) refferring to analysis of stomach contents of forest rodents were also applied, as were the methodological studies by Williams (1962) and Hanson (1970) facilitating identification of plant residue in stomach contents. The method used made it possible to obtain quantitative data (Gębczyńska \& Myrcha, 1966), and consisted in estimating the area (in $\%$ ) occupied by different components of diluted and homogenized stomach contents within the field of vision of a microscrope fitted with a measuring grid. Three preparations were made and analyzed from the contents of each stomach, and the final result constituted the average value from these estimates.

Identification of components of the vole's diet made it much easier to prepare reference models from known plant material. A large number of glycerine preparations were made from parts of plants which were presumable components of the vole's diet and were currently. available to these animals on the trapping area. Even better model preparations were obtained from stomach contents of test voles fed in the laboratory with given known species and parts of plants. The use of this method, however, necessitates obtaining a large number of animals, and it is therefore most convenient during periods of numerous occurrence of the common vole.

\subsection{Coefficient of Consumption of Plant Biomass Eliminated from Further Production}

The amount of plant biomass eliminated from further production $(M R)$ does not usually correspond to the amount of the animal's consumption $(C)$. The remaining part consists of so-called unused material $(N U)$, hence $M R=C+N U$ (Petrusewicz, 1967). Since it is possible, when estimating the role of the given herbivorous species in the ecosystem solely on the basis of known amount of consumption, greatly to under-estimate its effect in the majority of cases, it is essential to know $M R$ value in order to obtain correct estimates. It is often difficult to obtain an estimate of this value, and more often only an estimate of the animal's con- 
sumption in available $(C)$. On this account it is important to know the ratio $M R: C$, which makes further calculations possible.

These values were estimated under field conditions in lucerne, rye and rape crops. A total of 47 measurements were made, the majority ${ }_{(27)}$ on lucerne, where there was maximum density of the common vole, and 10 estimates each on the other crops. In the case of lucerne series of estimates were made during the time plants began to grow, during the period of luxuriant growth before the mowing, the between the first and second mowing, and between the second and third mowing and in autumn. Estimates were made in only two periods on rye and rape - after vegetation began and during the period preceding flowering of the plants. Later on the height and density of plants in the fields made it difficult to obtain accurate results.

Estimates were carried out as follows: a search was made for isolated, relatively compact vole colonies. Round the colony, in places in which the animals' feeding activities were evident, an area from 9 to $32 \mathrm{~m}^{2}$ was laid out. Before the estimate was begun in this area the weight of an average plant shoot of a cultivated plant was determined, and the existing damage to cultivated plants and weeds - traces of animals having fed on them (vole, hare, roe-deer etc.) was marked with quickly drying bright paint, and in the same way after the plants had been mown by agricultural machinery. After 14 days the weight of an average plant shoot was again estimated and a count made of the number of shoots eliminated during the estimate. By multiplying the number of shoots eliminated by the weight of an average shoot (average from two measurements), after adding the biomass of the weeds removed, an estimate was obtained of plant biomass eliminated by the vole colony during the period the estimate lasted $(M R)$. Rodents were next caught. Knowing the number and weight of voles in the colony, calculation was made from data in literature of their joint consumption $(C)$ and then the ratio $M R: C$.

The sum total of two values was used to estimate vegetation not used by the vole $(N U)$ : biomass of food residue left by the animals on the ground surface and in the tunnels of the colony, and the biomass of plants used to build nests. The biomass of nest material used by voles aver the course of a year in areas of cultivated plants with average density of animals was calculated from estimates of density and weight of nests. Estimates were made in spring, summer and autumn on lucerne, rye and rape crops. For this purpose the rodents' colonies found on $100 \mathrm{~m}^{2}$ areas of fields chosen at random were dug up and a count made of currently occupied or recently deserted nests. The nest miterial obtained was cleaned of impurities in the laboratory, then dried and weighed in accordance with accepted principles (temperature $85^{\circ}$, accuracy of weighing $0.1 \mathrm{~g}$ ).

\subsection{Effect of the Vole's Feeding Activities on Crop Yield}

The purpose of the experiments carried out under field conditions was to estimate the effect exerted by the common vole on crop yield by nibbling the upper parts of plants, and to distinguish periods of their intensified harmfulness.

Estimates were made for six crops: cereals (rye, winter wheat, barley, oats) and lucerne and rape. The vole's feeding activities were simulated on $0.25 \mathrm{~m}^{2}$ $(50 \times 50 \mathrm{~cm})$ plots by cutting off plants in the typical way used by this species of rodent. The plots were arranged in the crop in accordance with an accepted plan defining their distance in a row $(2 \mathrm{~m})$, distance between rows $(10 \mathrm{~m})$ and laying down exactly the order of distribution of plants differing as to the degree 
of elimination of plant biomass. In this way the repeatability of results and random nature of choice of plots in crops were ensured. The following degrees of extent of elimination of plant biomass were used: approx $10 \%, 33 \%, 50 \%$, $75 \%$ and $100 \%$. Elimination of about $50 \%$ of plant biomass from a plot corresponded e.g., to cutting off every other blade of cereal crop, shoot of lucerne, or removal of every other rape leaf. Plants on crops of winter cereals and rape were removed in two periods: in March-April, during the phase in which cereals develop, when rape had its first new leaves, and during the phase of formation of ears and flowering of rape in May. Additional estimates were made during the resting phase of plants in December-January. In the case of spring cereals removal of plant biomass was carried out only when ears were forming, whereas with lucerne cutting took place soon after growth had begun in spring, during the periods between mowings, and after the third mowing in October. Normally plants were removed once only from the same area, estimating the effect of this operation during harvesting (or mowing lucerne) and only on rye and rape crops were additional estimates made of the effect on the crop of cutting plants twice on the same plots. Each variant of the experiments made was repeated on 15 plots. At the same time plants were also taken from the same number of control plots.

Plants were taken from a total of 1350 plots. The plant biomass collected (in cereal and rape crops distinction was made between straw and grain) was dried and weighed in accordance with accepted principles.

\section{ACCEPTED ESTIMATES}

1. Using as a basis measurements of the body weight of 5000 voles obtained from different crops, in different trapping years and caught by different methods, it was found that average body weight of a vole from the study area was $18.5 \mathrm{~g}$.

2. Voles' length of life depends on a large number of ecological factors. There are many detailed estimates relating to the vole's age structure in lucerne crops, where it has been found that this parameter varies within wide limits depending on the season and phase of the population cycle of variations in numbers. On the basis of estimates and suggestions made by Martinet, 1968; Spitz, 1968; Adamczewska-Andrzejewska, 1974; Adamczewska-Andrzejewska \& Nabagło, 1977; Adamczewska-Andrzejewska (unpubl. data) the average length of a vole's life was taken to be 60 days. This is similar to Maksimov's estimate (1964) given after earlier studies by Soviet authors.

3. For the purpose of the present study the amount of average daily consumption by a vole weighing $18.5 \mathrm{~g}$ was taken as $15.0 \mathrm{kcal} /$ individual/day calculated from data contained in the paper by Sawicka-Kapusta et al., (1975).

4. In relation to the energy value of food consumed, $77.5 \%$ is assimilated. The energy value of excreted faeces is $18.7 \%$, urine $3.8 \%$ (Drożdz, 1968).

6. The caloria 'value of $1 \mathrm{gm}$ of dry mass of lucerne shoots was taken as' $4.4 \mathrm{kcal}$, rape $4.2 \mathrm{kcal}$, rye $4.1 \mathrm{kcal}$ (after estimates by Sawicka-Kapusta et al., 1975; Kukielska (in preparation)). On the basis of these data the average caloric value of the mass of upper parts of plants which form the basic food of the voles examined was taken as $4.2 \mathrm{kcal} / \mathrm{g}$ of dry mass.

7. Using estimates made by Sawicka-Kapusta et al. (1975) and data from industrial drying chambers, water content in the green mass of lucerne was taken as $80 \%, 85 \%$ in rye, $90 \%$ in rape. 
8. The amount of average primary production nett in agroeco:systems was taken, as the basis for syntheses of this type of material, as $1141 \mathrm{~g}$ dry mass $/ \mathrm{m}^{2} / \mathrm{year}$, where average biomass of the upper parts of plants forms $6: 3.3 \%$ of the whole primary production of cultivated plants (French et al., 1979).

The equation given in the paper by Ivlev (1955) was used to e:stimate preferences (for food, habitat), as follows:

$$
E=\frac{r_{1}-P_{1}}{r_{1}+P_{1}}
$$

where $E$ - preference index; $r_{1}$ - percentage of component in diet; $P_{1}$ - percentage of component in habitat. The value of the index takies on values from -1 to +1 , values in plus indicate preferences for a given component (element) from the habitat, values in minus - avoidance. Zero value and in the present study it was assumed also to include values in the interval from -0.2 to 0.2 , indicate proportionality, indifference.

The statistical significance of differences was calculated by means of the Student $t$ test.

\section{RESULTS}

\subsection{Numbers, Density, and Spatial Structure of the Vole Population}

Quantitative estimates of the vole population were made over a period of 5 years (1971-1975), tracing the full range of variations in the numbers of these rodents (Table 2). In 1971 and 1975 mass irruptions were record-

Table 2

Variation in the density of voles in cultivated fields (ind./ha).

\begin{tabular}{|c|c|c|c|c|c|c|c|}
\hline & & Lucerne & $\begin{array}{l}\text { Winter } \\
\text { rape }\end{array}$ & $\begin{array}{l}\text { Winter } \\
\text { cereal }\end{array}$ & $\begin{array}{l}\text { Spring } \\
\text { crops }\end{array}$ & $\begin{array}{l}\text { Root crops } \\
\text { and Inaize }\end{array}$ & $\begin{array}{c}\text { Avg. ha of } \\
\text { cultivated } \\
\text { fields }\end{array}$ \\
\hline 1971 & $\begin{array}{l}\text { Sp } \\
\text { Su } \\
\mathrm{Au}\end{array}$ & $\begin{array}{r}112 \\
1412 \\
1450\end{array}$ & $\begin{array}{r}41 \\
131 \\
204\end{array}$ & $\begin{array}{l}22 \\
84 \\
84\end{array}$ & $\overline{79}$ & -- & $\begin{array}{r}18 \\
173 \\
154\end{array}$ \\
\hline 1972 & $\begin{array}{l}\text { Sp } \\
\text { Su } \\
\mathrm{Au}\end{array}$ & $\begin{array}{r}125 \\
139 \\
82\end{array}$ & $\begin{array}{r}44 \\
10 \\
5\end{array}$ & $\begin{array}{r}40 \\
20 \\
0\end{array}$ & $\begin{array}{l}- \\
-\end{array}$ & - & $\begin{array}{r}26 \\
25 \\
7\end{array}$ \\
\hline 1973 & $\begin{array}{l}\mathrm{Sp} \\
\mathrm{Su} \\
\mathrm{Au}\end{array}$ & $\begin{array}{r}4 \\
32 \\
25\end{array}$ & $\begin{array}{l}1 \\
6 \\
1\end{array}$ & $\begin{array}{l}0 \\
3 \\
0.1\end{array}$ & $\overline{0}$ & 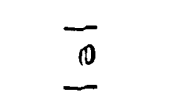 & $\begin{array}{l}0.4 \\
4 \\
2\end{array}$ \\
\hline 1974 & $\begin{array}{l}\mathrm{Sp} \\
\mathrm{Su} \\
\mathrm{Au}\end{array}$ & $\begin{array}{r}8 \\
20 \\
122\end{array}$ & $\begin{array}{r}2 \\
2 \\
45\end{array}$ & $\begin{array}{r}2 \\
6 \\
15\end{array}$ & $\begin{array}{r}- \\
-\end{array}$ & $\frac{1}{10}$ & $\begin{array}{r}1 \\
5 \\
17\end{array}$ \\
\hline 1975 & $\begin{array}{l}\mathrm{Sp} \\
\mathrm{Su} \\
\mathrm{Au} \\
\mathrm{ge}\end{array}$ & $\begin{array}{r}210 \\
1220 \\
480\end{array}$ & $\begin{array}{r}80 \\
105 \\
87\end{array}$ & $\begin{array}{l}36 \\
45 \\
38\end{array}$ & $\begin{array}{l}- \\
-\end{array}$ & $\overline{\mathbb{1}^{1}}$ & $\begin{array}{r}33 \\
131 \\
57\end{array}$ \\
\hline \multicolumn{2}{|c|}{$\begin{array}{l}\text { Average } \\
\text { estimate } \\
1971-1975 \\
\end{array}$} & 362 & 50 & 26 & 28 & 0 & 44 \\
\hline
\end{tabular}

Sp - Spring; Su - Summer; Au - Autumn. ${ }^{1}$ Approximate estïmate. - Crop did not occur during period estimates were made. 
ed, the 1971 irruption lasting longer than in 1975, and the density of voles being about $32 \%$ greater. In some lucerne fields the density of voles in the summer of 1971 reached a maximum number of nearly 3500 individuals/ha. Data for 1971 were taken as typical of the peak period of population numbers of this species, and data for 1973 as the minimum numbers, and the average estimate for 1972 and 1974 (period of the phase of decrease and increase during the cycle of variations in numbers) as the estimate of average states of population density.

Maximum density of voles was found in lucerne fields, where average density over a 5-year period was 362 individuals/ha, and was on an average about 7 times greater than in rape fields, and about 12 times greater than in cereals and spring crops (Table 2). The importance of different crops for the vole population in the study area is best described by the average percentage of the population in different crops out of the total number of voles present. This value is the function of density and area occupied by the given crop (Table 3 ). On an average on peren-

Table 3

Total number of voles present in the area of cultivated fields! (2150 ha).

\begin{tabular}{lrrrr}
\hline \multicolumn{1}{c}{ Crop } & $\begin{array}{c}\text { Peak } \\
\text { numbers } \\
(1971)\end{array}$ & $\begin{array}{c}\text { Minimum } \\
\text { numbers } \\
(1973)\end{array}$ & $\begin{array}{c}\text { Mean } \\
\text { numbers } \\
(1972,1974)\end{array}$ & $\begin{array}{c}\text { Percentage of the number of } \\
\text { voles from the given crop } \\
\text { in relation to those present } \\
\text { in the whole field area (1971) }\end{array}$ \\
\hline & & & & \\
Lucerne & 874,000 & 31,009 & 177,693 & 73.8 \\
Winter rape & 42,739 & 1,096 & 11,542 & 3.6 \\
Winter cereal & 237,228 & 4,215 & 81,003 & 20.0 \\
$\begin{array}{l}\text { Spring crops } \\
\text { Root crops and maize }\end{array}$ & 31,158 & 0 & 6,113 & 0.6 \\
Total & 0 & 0 & 0 & 100.0 \\
$\begin{array}{l}\text { Avg. no. of voles } \\
\text { per ha of }\end{array}$ & $1,185,125$ & 36,320 & 276,351 & \\
cultivated fields & & & & \\
\hline
\end{tabular}

nial crops, occupying $8.5 \%$ of the total area of crops, $73.8 \%$ of the voles living there are present, whereas only $20.0 \%$ occur in $34.7 \%$ of the area of winter cereals. The remaining crops are occupied by only $6 \%$ of the voles present (Table 3). When the value of the percentage of voles from perennial crops out of the total numbers $\left(r_{1}\right)$ is placed in Ivlev's equation, we obtain a coefficient of +0.77 , which is evidence of the high degree of preference by the vole population in its occupation of the crops. The above data are characteristic of the distribution of the vole population in an area of cultivated land. Even in years of high numbers the vole population does not occupy the whole area of crops. It is only exceptionally that single individuals occupy a large area $(28.5 \%$ of the area) 
of root crops and maize. In years when numbers are minimum a small number of vole colonies persist only on perennial crops, meadows, edges of shelterbelts, grass boundaries between fields etc. The area of such places of shelter for the vole population is about $19 \%$ of the study area (Table 1).

\subsection{The Vole's Food Supply}

The harvesting method was used to estimate primary production of the upper parts of the five plant species most numerously occupied by the vole population (Table 4). Maximum biomass production of the upper

Table 4

Average primary production (crop) of the upper parts of cultivated plants and of weeds.

\begin{tabular}{|c|c|c|c|c|c|c|c|c|}
\hline \multicolumn{3}{|c|}{$\begin{array}{c}\text { Cultivated plants } \\
\text { Biomass in } \mathrm{g} \text { dry mass } / \mathrm{m}^{2} \\
\end{array}$} & \multirow[t]{2}{*}{ Weeds } & \multirow[t]{2}{*}{ Total } & \multicolumn{3}{|c|}{$\begin{array}{l}\text { Cultivated plants } \\
\text { Percentage of biomass }\end{array}$} & \multirow[b]{2}{*}{ Weeds } \\
\hline Grain & Shoots & $\begin{array}{l}\text { Combinated } \\
\text { grain and } \\
\text { shoots }\end{array}$ & & & Grain & Shoots & $\begin{array}{l}\text { Combinated } \\
\text { grain and } \\
\text { shoots }\end{array}$ & \\
\hline & 865.0 & $\cdot$ & $\begin{array}{l}\text { Lucerne } \\
72.9 \\
\text { Rape }\end{array}$ & 937.9 & & 92.2 & & 7.8 \\
\hline 305.6 & 631.5 & 940.1 & $\begin{array}{l}16.4 \\
\text { Rye }\end{array}$ & 956.5 & 31.9 & 66.4 & 98.3 & 1.7 \\
\hline 356.2 & 569.0 & 925.2 & $\begin{array}{l}17.9 \\
\text { Wheat }\end{array}$ & 935.2 & 37.4 & 60.8 & 98.2 & 1.8 \\
\hline 377.2 & 422.0 & 799.2 & $\overline{\text { Oats }}$ & 799.2 & 47.1 & 52.9 & - & - \\
\hline 347.8 & 354.4 & 702.2 & $\overline{\text { Barley }}$ & 702.2 & 49.5 & 50.5 & - & - \\
\hline 398.4 & 330.4 & 728.8 & - & 728.8 & 54.6 & 45.4 & - & - \\
\hline
\end{tabular}

parts of plants was found in the rape crop (956.5 dry mass $\left./ \mathrm{m}^{2}\right)$, lucern" (937.9 g dry mass $\left./ \mathrm{m}^{2}\right)$ and rye $\left(935.2 \mathrm{~g}\right.$ dry mass $\left./ \mathrm{m}^{2}\right)$. Maximum grain yield per unit area was obtained from barley $\left(398.4 \mathrm{~g}\right.$ dry $\left.\operatorname{mass} / \mathrm{m}^{2}\right)$ and wheat (377.2 dry mass $\left./ \mathrm{m}^{2}\right)$. The proportions in biomass formed were distinguished by grain, shoots and weeds in the value of primary production. The data obtained point to the enormous simplification of plant associations in cultivated fields under conditions of advanced agricultural management. Almost $100 \%$ of plant biomass in the field consists of the biomass of cultivated plants (Table 4). Only $12-15$ species of weeds occur in some fields and their basic biomass $(80-90 \%)$ is formed by only $3-4$ species (Tables $5-7$ ). The species most numerously occurring in the lucerne field are Poa annula L., Stellaria media Vill., Agropyron repens 
Table 5

Weeds occurring in lucerne crop ${ }^{1}$.

\begin{tabular}{lcc}
\hline \multicolumn{1}{c}{ Species } & $\begin{array}{c}\text { Percentage by weight } \\
\text { in weed biomass }\end{array}$ & $\begin{array}{c}\text { Frequency of } \\
\text { occurrence, \% }\end{array}$ \\
\hline & & \\
Poa annua L. & 29.3 & 42 \\
Stellaria media Vill. & 14.0 & 23 \\
$\begin{array}{l}\text { Agropyron repens (L.) P.B. } \\
\text { Chenopodium album L. }\end{array}$ & 12.9 & 20 \\
Taraxacum officinale Web. & 4.3 & 16 \\
Plantago major L. & 2.7 & 31 \\
Capsella bursa-pastoris (L.) Med. & 2.5 & 14 \\
Polygonum aviculare L. & 1.8 & 7 \\
Rumex acetosa L. & 0.6 & 8 \\
Erodium cicutarium (L.) L'Herit & 0.3 & 6 \\
Plantago lanceolata L. & 0.1 & 4 \\
Lolium perenne L. & 0.1 & 2 \\
Convolvulus arvensis L. & 0.1 & 2 \\
Veronica arvensis L. & 0.1 & \\
\hline
\end{tabular}

1 The data presented constitute the mean estimate from 3 measurements made during periods of successive mowing of lucerne.

Table 6

Weeds occurring in rape crop.

\begin{tabular}{lcc}
\hline \multicolumn{1}{c}{ Species } & $\begin{array}{c}\text { Percentage by weight } \\
\text { in weed biomass }\end{array}$ & $\begin{array}{c}\text { Frequency of } \\
\text { occurrence, \% }\end{array}$ \\
\hline & & \\
Stellaria media Vill. & 36.5 & 43 \\
Poa pratensis L. & 22.1 & 31 \\
Myosotis arvensis (L.) Mill. & 12.3 & 23 \\
Capsella bursa-pastoris (L.) Med. & 9.8 & 14 \\
Centaurea cyanus L. & 7.7 & 10 \\
Poa annua L. & 4.0 & 10 \\
Matricaria discoidea D.C. & 2.9 & 8 \\
Viola arvensis Murr. & 2.1 & 1 \\
Apera spica-venti (L). P.B. & 0.8 & 2 \\
Raphanus raphanistrum L. & 0.8 & 1 \\
Agropyron repens (L.) P.B. & 0.5 & 2 \\
Lamium purpureum L. & 0.5 & \\
\hline
\end{tabular}

(L.) P.B., on rape Stellaria media Vill., Poa pratensis L., Myosotis arvensis (L.) Hill, on rye Apera spica-venti (L.) P.B., Viola arvensis Murr. and Echinochloa crus-galli (L.) P.B. Species forming a large proportion of biomass are usually distinguished by great frequency of occurrence in samples and as they occur numerously over the whole area are relatively available for voles. The percentage of weeds in total biomass of plants in the field is very low during the harvest period (Table 4). It is only in lucerne that the percentage of weeds approaches $10 \%$ of biomass. The reciprocal ratio of these values over the whole of the growing season 
Table 7

Weeds occurring in rye crop.

\begin{tabular}{lcc}
\hline \multicolumn{1}{c}{ Species } & $\begin{array}{c}\text { Percentage by weight } \\
\text { in weed biomass }\end{array}$ & $\begin{array}{c}\text { Frequency of } \\
\text { occurrence, \% }\end{array}$ \\
\hline & & \\
Apera spica-venti (L.) P.B. & 51.6 & 48 \\
Viola arvensis Murr. & 16.6 & 40 \\
Echinochloa crus-galli (L. P.B. & 11.1 & 38 \\
Centaurea cyanus L. & 4.5 & 8 \\
Chenopodium album L. & 4.5 & 4 \\
Spergula arvensis L. & 4.5 & 10 \\
Rumex acetosella L. & 1.5 & 2 \\
Myosotis arvensis (L.) Hill. & 1.5 & 2 \\
Erodium cicutarium (L.) L'Herit & 0.7 & 2 \\
Polygonum persicaria L. & 0.7 & 1 \\
Equisetum arvense L. & 0.7 & 1 \\
Stellaria media Vill. & 0.7 & 1 \\
Polygonum convolvulus L. & 0.7 & 1 \\
Scleranthus annuus L. & 0.7 & 1 \\
Veronica arvensis L. & 0.7 & \\
\hline
\end{tabular}

Table 8

Agricultural crop yield (in $\mathrm{g}$ dry mass/ha) of main cultivated plants inhabitated by the vole ${ }^{1}$.

\begin{tabular}{lllcccc}
\hline \multirow{2}{*}{ Type of crop } & & \multicolumn{3}{c}{ Years } & Avg. for $\begin{array}{c}\text { Average } \\
\text { for type } \\
\text { of crop }\end{array}$ \\
\cline { 3 - 5 } & & 1973 & 1974 & 1975 & $1973-1975$ & \\
Perennial plants & Lucerne & 830 & 790 & 900 & 840 & \\
(plant biomass) & Grasses & 800 & 890 & 900 & 863 & 862 \\
Rape (grain) & & 234 & 252 & 234 & 240 & 240 \\
Winter cereal & Rye & 338 & 304 & 328 & 323 & \\
(grain) & Wheat & 336 & 296 & 408 & 346 & 335 \\
Spring cereal & Oats & 247 & 424 & 350 & 340 & \\
(grain) & Barley & 370 & 402 & 336 & 369 & 355 \\
\hline
\end{tabular}

1 Data from the State Farm at Turew.

is more marked. The proportion of weeds in lucerne during periods when the crop starts growing in spring, and during its slower growth in autumn, increases considerably to $30-40 \%$ (Table 9). Also a far higher proportion of weed biomass was several times found in the rape crops during the resting period in relation to rape biomass than during the period of its strong growth. This was due to mass development of Stellaria media Vill., which successfully overwintered (Table 10).

Comparison was made of the authors' own estimates of plant production with agricultural estimates of crop yields obtained in the study area (Table 8). In every case the yield shown by the State Farms was lower 
- in lucerne approx. $10 \%$, in cereals about $12 \%$, and in rape about $20 \%$ lower. The difference found may be explained by a number of causes, although it would seem that these differences chiefly illustrated the amount of losses caused by mechanical harvesting of plants. The reciprocal ratios of these values are in agreement with practical suggestions.

\subsection{Composition of the Vole's Diet}

The composition of the vole's diet was estimated for the three basic crops in which the population usually attains maximum density - lucerne, rape and rye. There are no quantitative estimates of the vole's diet

Table 9

The vole's diet in relation to plant biomass structure in a lucerne crop.

a - Percentage of component in diet ( $\%$ by weight),

$\mathrm{b}$ - Percentage of component in plant biomass $(\%$ by weight),

c - Value of food preference index $E$,

$n$ - Non-significant value of index $E$.

\begin{tabular}{|c|c|c|c|c|c|}
\hline & & Lucerne & Weeds & $\begin{array}{l}\text { Underground } \\
\text { parts of plants }\end{array}$ & Others \\
\hline $\begin{array}{l}\text { Before first } \\
\text { mowing }\end{array}$ & $\begin{array}{l}a \\
b \\
c\end{array}$ & $\begin{array}{c}74.5 \\
70.4 \\
\mathrm{n}\end{array}$ & $\begin{array}{c}20.8 \\
29.6 \\
n\end{array}$ & 3.3 & 1.4 \\
\hline First mowing & $\begin{array}{l}\mathrm{a} \\
\mathrm{b} \\
\mathrm{c}\end{array}$ & $\begin{array}{c}94.0 \\
96.8 \\
\mathrm{n}\end{array}$ & $\begin{array}{l}4.6 \\
3.2 \\
\mathrm{n}\end{array}$ & 0.8 & 0.6 \\
\hline Second mowing & $\begin{array}{l}\mathrm{a} \\
\mathrm{b} \\
\mathrm{c}\end{array}$ & $\begin{array}{c}80.7 \\
86.2 \\
n\end{array}$ & $\begin{array}{c}17.8 \\
13.8 \\
\mathrm{n}\end{array}$ & 0.6 & 0.9 \\
\hline Third mowing & $\begin{array}{l}a \\
b \\
c\end{array}$ & $\begin{array}{c}83.4 \\
93.2 \\
n\end{array}$ & $\begin{array}{c}13.9 \\
6.7 \\
+0.34\end{array}$ & 0.8 & 1.9 \\
\hline $\begin{array}{l}\text { After third } \\
\text { mowing }\end{array}$ & $\begin{array}{l}a \\
b \\
c\end{array}$ & $\begin{array}{c}26.2 \\
55.3 \\
-0.28\end{array}$ & $\begin{array}{c}62.5 \\
44.7 \\
\mathrm{n}\end{array}$ & 7.4 & 3.9 \\
\hline $\begin{array}{l}\text { Whole } \\
\text { growing } \\
\text { period } \%\end{array}$ & $\begin{array}{l}a \\
b \\
c\end{array}$ & $\begin{array}{c}71.8 \\
80.4 \\
\mathrm{n}\end{array}$ & $\begin{array}{c}23.9 \\
16.6 \\
\mathrm{n}\end{array}$ & 2.6 & 1.7 \\
\hline
\end{tabular}

so far in literature. The existing relative estimates, based on frequency of components in stomach contents, related to rodents caught in habitats other than the open areas of cultivated fields in which the main part of the population of this species lived in the study area.

It was found, in accordance with suggestions and estimates contained in a large number of papers, that over the period of the whole year the vole in cultivated fields is a decided consumer of the green mass of plants (Table 9-11). The proportion of this component in diet is 


\section{Table 10}

The vole's diet in relation to plant biomass structure in a rape crop.

a - Percentage of component in diet $(\%$ by weight),

$\mathrm{b}$ - Percentage of component in plant biomass ( $\%$ by weight),

$c$ - Value of food preference index $E$,

$n-$ Non-significant value of index $E$.

\begin{tabular}{|c|c|c|c|c|c|c|c|}
\hline & \multicolumn{2}{|c|}{ Rape } & \multicolumn{2}{|c|}{ Weeds } & \multicolumn{2}{|l|}{ Underground } \\
\hline & & Shoots & Seeds & Shoots & Seeds & parts of plants & Others \\
\hline Winter resting & $\begin{array}{l}a \\
b\end{array}$ & $\begin{array}{l}86.2 \\
93.1\end{array}$ & & $\begin{array}{l}9.1 \\
6.9\end{array}$ & 0.9 & 3.8 & 1.0 \\
\hline $\begin{array}{l}\text { period } \\
\text { (Nov-Feb) }\end{array}$ & $\mathrm{c}$ & $\mathrm{n}$ & & $n$ & & & \\
\hline $\begin{array}{l}\text { Start of } \\
\text { growing } \\
\text { (March-April) }\end{array}$ & $\begin{array}{l}a \\
b \\
c\end{array}$ & $\begin{array}{c}90.0 \\
97.4 \\
\mathrm{n}\end{array}$ & & 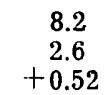 & & 0.2 & 0.7 \\
\hline $\begin{array}{l}\text { Flowering } \\
\text { (May) }\end{array}$ & $\begin{array}{l}a \\
b \\
c\end{array}$ & $\begin{array}{c}85.9 \\
98.5 \\
\mathrm{n}\end{array}$ & & $\begin{array}{r}12.1 \\
1.4 \\
+0.79\end{array}$ & 0.1 & 0.2 & 1.8 \\
\hline $\begin{array}{l}\text { Maturation } \\
\text { of plants } \\
\text { harvest } \\
\text { (June-July) }\end{array}$ & $\begin{array}{l}a \\
b \\
c\end{array}$ & $\begin{array}{c}70.0 \\
66.4 \\
\mathrm{n}\end{array}$ & $\begin{array}{c}8.3 \\
31.9 \\
-0.59\end{array}$ & $\begin{array}{c}18.2 \\
1.1 \\
+0.88\end{array}$ & $\begin{aligned} & 1.2 \\
& 0.6 \\
&+ 0.33\end{aligned}$ & 0.1 & 2.2 \\
\hline $\begin{array}{l}\text { Whole } \\
\text { growing } \\
\text { period }\end{array}$ & $\begin{array}{l}a \\
b \\
c\end{array}$ & $\begin{array}{c}83.2 \\
88.8 \\
n\end{array}$ & & $\begin{array}{r}11.9 \\
3.0 \\
+0.60\end{array}$ & & 1.2 & 1.2 \\
\hline
\end{tabular}

Table 11

The vole's diet in relation to plant biomass structure in a rye crop.

\begin{tabular}{|c|c|c|c|c|c|c|c|}
\hline & \multicolumn{2}{|c|}{ Rape } & \multicolumn{2}{|c|}{ Weeds } & Underground & \multirow[b]{2}{*}{ Others } \\
\hline & & Shoots & Seeds & Shoots & Seeds & parts of plants & \\
\hline Winter resting & $\begin{array}{l}a \\
b\end{array}$ & $\begin{array}{l}88.7 \\
97.2\end{array}$ & 0.1 & $\begin{array}{l}5.6 \\
2.8\end{array}$ & & 4.9 & 0.7 \\
\hline $\begin{array}{l}\text { period } \\
\text { development }\end{array}$ & c & $\mathrm{n}$ & & +0.33 & & & \\
\hline Formation of & $\begin{array}{l}a \\
b\end{array}$ & $\begin{array}{l}91.8 \\
98.0\end{array}$ & & $\begin{array}{l}5.1 \\
2.0\end{array}$ & & 0.3 & 2.8 \\
\hline blades & c & $\mathrm{n}$ & & +0.43 & & & \\
\hline $\begin{array}{l}\text { Formation } \\
\text { of ears, } \\
\text { flowering }\end{array}$ & $\begin{array}{l}a \\
b \\
c\end{array}$ & $\begin{array}{c}91.6 \\
98.4 \\
\mathrm{n}\end{array}$ & & $\begin{aligned} & 7.4 \\
& 1.6 \\
&+ 0.64\end{aligned}$ & & 0.1 & 0.9 \\
\hline $\begin{array}{l}\text { Maturation, } \\
\text { harvest }\end{array}$ & $\begin{array}{l}a \\
b \\
c\end{array}$ & $\begin{array}{c}81.9 \\
60.8 \\
n\end{array}$ & $\begin{array}{c}10.1 \\
37.4 \\
-0.57\end{array}$ & $\begin{array}{r}5.3 \\
1.2 \\
+0.63\end{array}$ & $\begin{array}{l}0.4 \\
0.6 \\
-0.20\end{array}$ & 0.1 & 2.2 \\
\hline $\begin{array}{l}\text { Whole } \\
\text { growing } \\
\text { period } \\
\end{array}$ & $\begin{array}{l}a \\
b \\
c\end{array}$ & $\begin{array}{c}88.5 \\
88.6 \\
n\end{array}$ & & $\begin{array}{r}5.8 \\
1.9 \\
+ \\
+0.50\end{array}$ & & 1.3 & 1.6 \\
\hline
\end{tabular}

frequently close to $100 \%$, and is usually not less than $90 \%$ of the biomass consumed. The parts of plants below ground $(0.1-7.4 \%$ of the vole's diet) form a very small value. Their proportion increases slightly 
during periods of some insufficiency, or reduction in the value of food (autumn, winter, early spring). A negligible percentage of their food was found to be formed by invertebrates $(0.1-1.1 \%)$. Its amount increases gradually from spring to early autumn, and is highest during the period of intensive reproduction in the population. During the maturation periods of the seeds of cultivated plants and weeds, the vole partly feeds on them. Their percentages in its diet in cereal and rape crops are, however, only about $10 \%$, which does not in principle alter the reciprocal proportions of the chief components of its diet - the green: parts of cultivated plants and weeds, and roots and rhizomes (Tables $9-11)$.

Comparison was made of the percentages of differert components in the structure of the vole's diet with their percentages in the weight structure of plant biomass. Ivlev's equation (1955 - see section 4) was used, taking the low values obtained for index $E$ in the range from -0.20 to +0.20 as absence of food preferences. Analysis of data collected points to preferences (through the greater part of the growing season) for consuming weeds in cereal and rape crops (Tables 10, 11). The percentage of cultivated plant biomass in the vole's diet is then correspondingly lower than its percentage in the composition of total plant biomass. A relation of this type was found in the lucerne crop in autumn, when the plant's capacity for regrowth decreases after shoots have been mown, as does its food value. Voles then prefer weeds $(E=+0.34)$, their percentage in their diet during this period exceeding the percentage of lucerne $(E=-0.28)$, while the percentage of the underground parts of plants increases in their diet (Table 9). The percentage of rye and rape grain in the vole's diet is not in proportion to produced biomass but is $3-4$ times lower $(E=-0.59 ;-0.57)$. The seeds of weeds are a preferred food in the rape crop, but are more or less avoided in rye $(E=-0.20)$, but these relations are not distinct. The percentages of this component in both diet and total plant biomass are so small that it is more correct to speak of finding proportional consumption of the seeds of weeds.

In addition to the three species of cultivated plants 29 weed species occurred in the study fields. In estimating the vole's food preferences in relation to weeds it was found that almost all species are eaten in principle proportionately to their percentage in plant biomass (value of coefficient $E$ between $-0.20+0.20$ ). The vole exhibits a faint preference only for Stellaria media Vill. and Taraxacum officinale Web in lucerre, and Poa pratensis L. in rape. The following weed species occurring in crops were not found in the composition of the vole's diet: Convolvulus arvensis L., Equisetum arvense L., Erodium cicutarum (L.) L'Herit., 
Matricaria discoidea Dc. These species form only a small percentage $(0.1-2.9 \%)$ in the weed biomass of the crops examined.

\subsection{Estimate of Amount Consumed by the Vole in Relation to Plant Biomass Eliminated from Further Production}

The value of the ratio $M R: C$ was estimated experimentally in three crops : lucerne, rye and rape, during different stages of development of these plants. Ratio $M R: C$ below 2.0 indicates the predominance of the amount consumed by the vole over eliminated biomass (plants cut down) by the vole but not used as food, ratio over 2.0 - predominance of unused biomass over that consumed. By multiplying the amount of consumption by the value $M R: C$ it is possible to estimate the whole biomass eliminated by the animals from further plant production.

The greatest fluctuations in the results obtained were found in the lucerne crop. Ratio $M R: C$ varied from 1.9 in early spring to 7.0 in late summer (Table 12). This means that the voles consume $52 \%$ of the

Table 12

Average ratio of plant biomass consumed by voles $(C)$ to that eliminated from further production $(M R)$ indifferent months.

\begin{tabular}{|c|c|c|c|c|c|c|c|c|c|c|c|c|}
\hline & \multicolumn{2}{|c|}{ Mar-Apr } & \multicolumn{2}{|c|}{ May } & \multicolumn{2}{|c|}{ June } & \multicolumn{2}{|c|}{ Jul_Aug } & \multicolumn{2}{|c|}{ Sep-Oct } & \multicolumn{2}{|c|}{ Nov-Oct } \\
\hline & $C: M R$ & $\mathrm{n}$ & $C: M R$ & $\mathrm{n}$ & $C: M R$ & $\mathrm{n}$ & C : $M R$ & $\mathrm{n}$ & $C: M R$ & $\mathrm{n}$ & $C: M R$ & $n$ \\
\hline Lucerne & 1.9 & 4 & 4.8 & 5 & 6.7 & 5 & 7.0 & 7 & 1.6 & 6 & 4.4 & 27 \\
\hline $\begin{array}{l}\text { Rape } \\
\text { Rye }\end{array}$ & $\begin{array}{l}3.4 \\
1.2\end{array}$ & $\begin{array}{l}5 \\
5\end{array}$ & $\begin{array}{l}1.8 \\
4.9\end{array}$ & $\begin{array}{l}15 \\
5\end{array}$ & - & 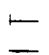 & $=$ & $\overline{-}$ & - & - & 2.6 & 10 \\
\hline
\end{tabular}

$\mathrm{n}=$ number of estimate made

biomass of eliminated plants in spring, but only $14 \%$ in summer. This value increases over the course of the growing season as the food value of lucerne decreases, particularly abruptly between the first and second mowing. In rape and rye crops this ratio was estimated during the development and flowering phases of plants, when there was a maximum amount of fresh green biomass in the field. In early, spring, however, the voles consume proportionately less rye and rape in relation to the biomass of eliminated plant biomass than is the case with lucerne. Later on this value decreases in the rape crop, but continues to increase in rye. This can be accounted for by the different way in which the vole makes use of plants during this period. At that time the vole bites off whole shoots of cereals, but consumes only certain parts of them. In rape, on the other hand, it ceases to eliminate the whole plants, which are by then large and hard, and feeds chiefly on juicy leaves, new growth, weak or flattened plants. The role of weeds also becomes more 
important in the animal's diet (Table 10). On an average during the period estimates were made voles consumed $23 \%$ of eliminated biomass, $38 \%$ of rape and $33 \%$ of rye (Data in table 12 ).

The biomass of the nests examined forms part of eliminated but not consumed biomass $(N U)$. This value was estimated in a year of average numbers in the lucerne, rape and rye crops. The average weight of a vole nest varies very little over the course of a year (Table 13). It was most stable in the lucerne crop, but among annual plants increased characteristically before the winter period, when the average weight of nests built there was higher than in lucerne. In view of the slight variations in nest weight the general result obtained for estimated biomass of used nest material per unit of area is chiefly the function. of the density of rodents occurring there. Hence in lucerne the value

\section{Table 13}

Weight of material used to build nests in $\mathrm{g}$ dry mass/ha/year (year with average density of voles).

\begin{tabular}{llccc}
\hline & & Lucerne & Rape & Rye \\
\hline \multirow{2}{*}{ Spring } & & & & \\
& Avg. wt of nest, g & 135 & 33 & 18 \\
& No. of. nests/ha & 10.5 & 10.3 & 10.1 \\
Summer & Wt. of nest material/ha & 1,417 & 340 & 182 \\
& Avg. wt. of nest, g & 550 & 62 & 27 \\
& No. of nests/ha & 10.1 & 10.3 & 8.7 \\
Autumn & Wt. of nest material/ha & 5,500 & 637 & 235 \\
& Avg. wt. of nest, g & 530 & 57 & 36 \\
Wt. of nest & No. of nests/ha & 10.9 & 13.7 & 11.2 \\
material, g dry & & 5.777 & 781 & 403 \\
mass/ha/year & & & & \\
\hline
\end{tabular}

is seven times greater than on rape and more than fifteen times greater than on the same area of the rye crop (Table 13).

The number of rodents caught per unit of area in relation to the number of nests present there is a variable value, fluctuating from 1.1 to 2.6 individuals/nest. This ratio increases from spring to autumn, which is undoubtedly connected with the rodent's reproduction.

\subsection{Effect of the Vole's Feeding on Changes in Cultivated Plant Yield}

By consuming the green mass of plants the vole may affect the crop yield obtained by man. This species feeds directly on grain only for a short period during harvest time, and even then grain fails to form a basic element of its diet. By simulating, under controlled conditions, nibbling of plants by the vole by diversifying the amount of biomass 
eliminated on the plots and the action at different phases of plant development, an estimate was made of the effect of these factors on crop yield.

Plants were found to react differently to the vole's feeding activities. Cereals have two periods of completely different reaction. In the first period, occurring during the development phase of cereals (autumn, winter, early spring - winter cereals; April, early May - spring cereals) these plants react only slightly to damage in respect of crop yield. In summer, within the estimated plots, crop yield did not differ statistically from the crop yield obtained in control plots. After removal of $100 \%$ of the upper biomass of rye there was from 320 to $305 \mathrm{~g}$ dry mass $/ \mathrm{m}^{2}$, and in wheat from 396 to $364 \mathrm{~g}$ of $\mathrm{dry} \operatorname{mass} / \mathrm{m}^{2}$. When

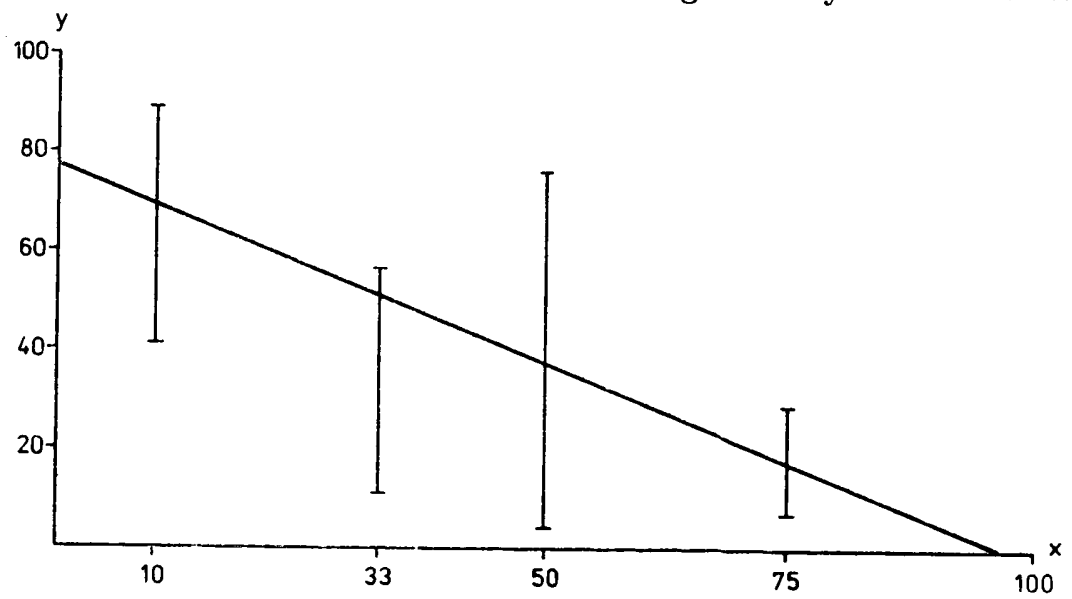

Fig. 1. Effect of removing rye shoots during ear-forming period on grain crop. $y$ - Grain crop in $\mathrm{g} / 0.25 \mathrm{~m}^{2} ; x-$ Percentage of biomuss elimination. $y=-0.81 x+$ $77.6 ; r=-0.81 ; \mathrm{n}=35$

plants are cut down twice during this development phase (in December and again in March) the crop yield of rye and winter wheat was not found to decrease. During the development phase of cereals it was even found that slight losses in biomass cause a certain degree of stimulation to the plant's development. As an example removal of $50 \%$, of wheat and barley blades caused on an average $2-6 \%$ increase in grain biomass (the difference is not statistically significant).

During the period when blades shoot up, ears form and flowering takes place cereals react strongly to damage by decreased crop yjeld. The animals feeding during this period destroy the already formed rudiment of ears and a plant injured in this way (its shoot) does not yield a crop. The decrease in crop yield is correlated with the value of biomass eliminated (Fig. 1-4). Rye and oats, after removal of $50 \%$ of 
the blades during this period, yield only one half of the control crop yield and removal of the whole biomass above ground (100\% of blades) completely eliminates grain yield (although the plants still give a certair biomass of barren regrowths). Wheat and barley are more resistant to nibbling by these animals and were found to react by $50 \%$ decrease in crop yield only after about $70 \%$ of the shoots have been removed. Even $100 \%$ removal of shoots fails to cause complete loss of crop from these plants. Part of the regrown shoots still manage to produce grain. The crop yield is, however, low (not quite 10\% of the control crop yield) and the grain of poor quality (Fig. 3-4).

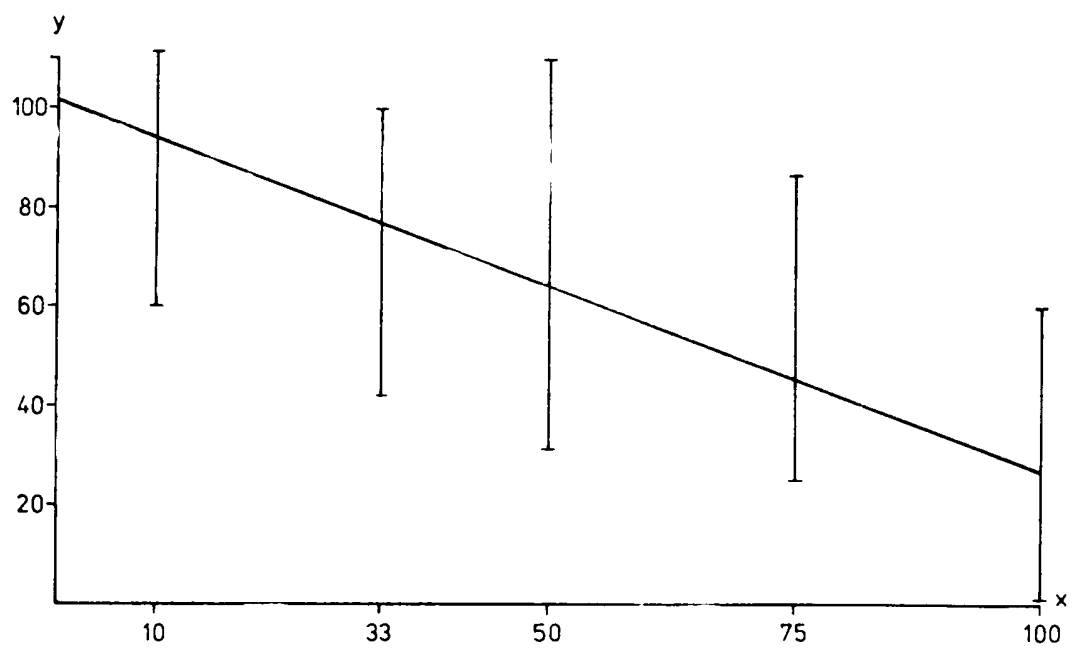

Fig. 2. Effect of removing oat shoots during ear-forming period on grain crop. $y$ - Grain crop in $\mathrm{g} / 0.25 \mathrm{~m}^{2} ; x$ - Percentage of biomass elimination. $y=-1.13 x+$ $116.4 ; r=-0.88 ; \mathrm{n}=50$

Rape reacts to removal of biomass in a different way from cereals It was found that voles may cause maximum losses in this crop during the period when the plants are still weakly developed, that is, in autumn, winter and early spring. Removal of leaves during these periods causes weakening and even destruction of plants. Removal of $33 \%$ of leaves caused $55 \%$ drop in crop yield, and removal of $75-100 \%$ of larger leaves by as much as $75 \%$ (Fig. 5). Decrease in biomass of whole plants (after deduction of grain biomass) is slower (analogically about 35 and $55 \%$ ). As this same regularity, was observed in cereal crops (Fig. 3) a general conclusion may be reached that damage to plants most strongly contributes to a decrease in grain biomass.

During subsequent development phases of rape the voles cease cutting 


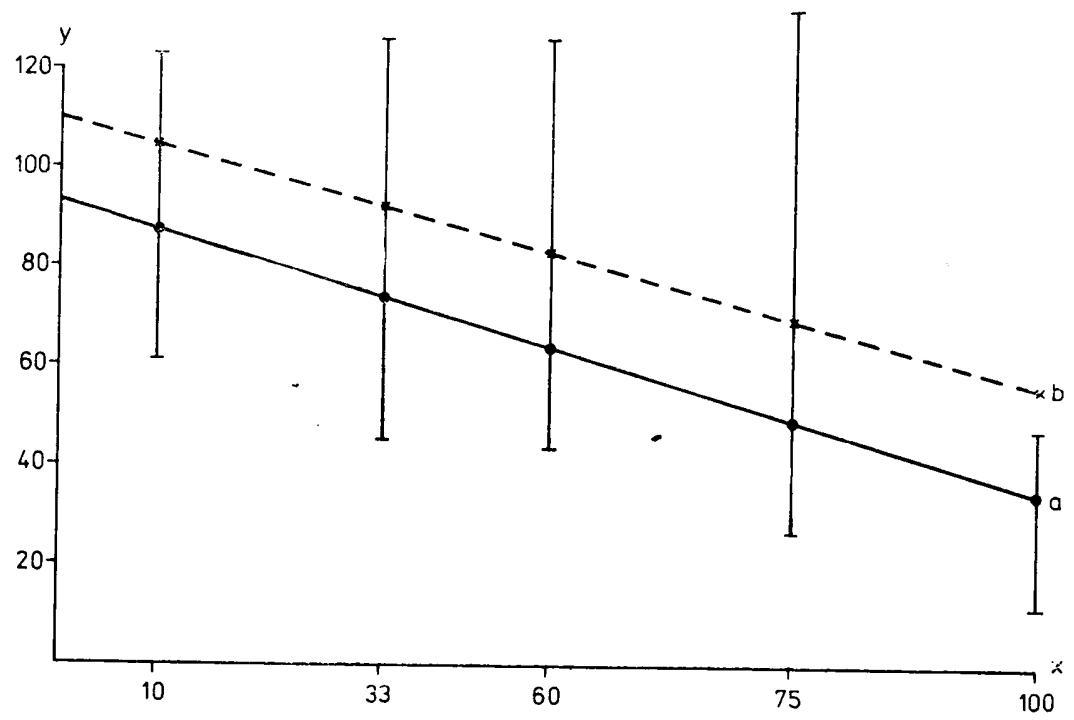

Fig. 3. Effect of removing barley shoots during ear-forming perioa (a) $u_{i x}$ grain crop and (b) on straw crop.

$y$ - Crop in $\mathrm{g} / 0.25 \mathrm{~m}^{2} ; x$ - Percentage of biomass elimination.

a) $y=-0.57 x+93.7 ; r=-0.86 ; \mathrm{n}=75$

b) $y=-0.50 x+109.4 ; r=-0.63 ; \mathrm{n}=75$

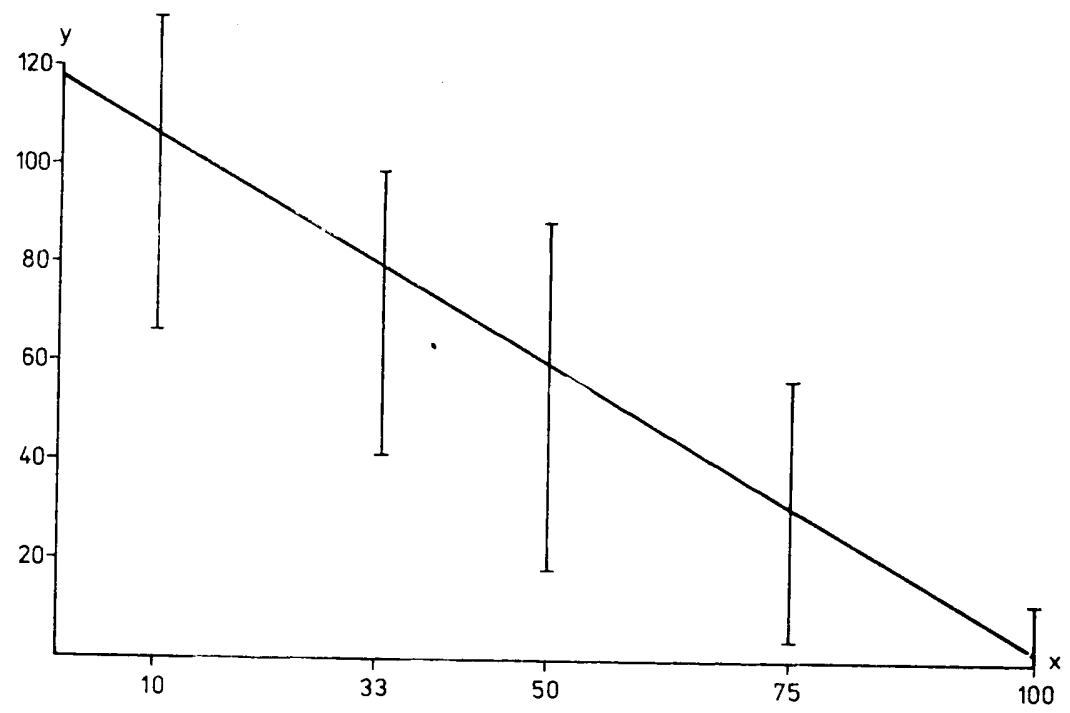

Fig. 4. Effect of removing wheat shoots during ear-forming period on grain crop. $y$ - Grain crop in $\mathrm{g} / 0.25 \mathrm{~m}^{2} ; x$ - Percentage of biomass elimination. $y=-0.75 x+102.1 ; r=-0.83 ; \mathrm{n}=75$ 


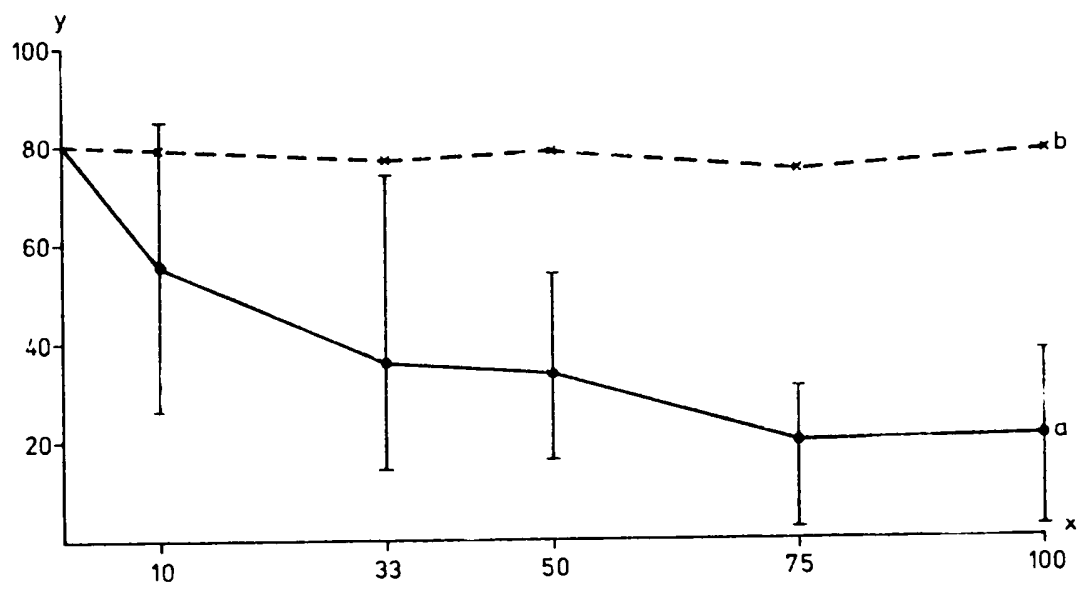

Fig. 5. Effect of removing rape leaves during start of growing period (a) and flowering period (b) on grain crop.

$y$ - Grain crop in $\mathrm{g} / 0.25 \mathrm{~m}^{2} ; x$ - Percentage of biomass elimination.

down whole normally developed rape plants. They remove single leaves, plants slow in development or those lying on the soil etc. Analogical removal of biomass, regardless of its intensity $(33-100 \%)$ does not cause a statistically significant drop in grain crop yield.

Lucerne reacts differently to removal of part of its biomass during the growing period. In spring before the first mowing, removal of part of the shoots stimulates the plants' growth. This process intensifies with increase in the biomass removed. During the first mowing of lucerne on plots from which in addition $100 \%$ of the upper biomass of lucerne

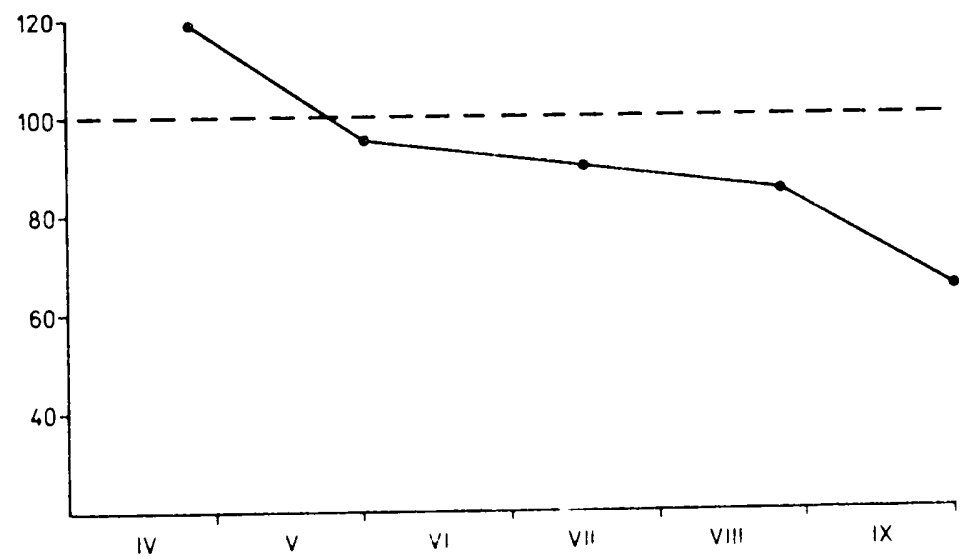

Fig. 6. Reduction in regeneration capacity of lucerne as growing season proceeds (complete removal of biomass, biomass of average control sample taken as $100 \%$ ). $y$ - Percentage of biomass in relation to control crop; $x$ - months. 
had been removed, an almost $20 \%$ greater increase in lucerne crop was found in relation to the control plots (Fig. 6). During the period between the first and second mowing the plants still regenerate lost biomass (5\% reduction in crop yield, but the difference is not statistically significant). Later on lucerne losses increase as the result of additional cutting, that is, simulated feeding of these rodents. During the third mowing period losses in lucerne biomass were $15 \%$, and in autumn at the end of September-October as much as approx. $35 \%$. The results point to the decreasing regenerative capacity of lucerne during the course of the growing season.

\subsection{Effect of the Vole on the Vegetation of Cultivated Fields}

The simultaneous effect of several estimated factors of a vole population: density, diet, effect on crops over the full cycle of its variations in numbers in a large study area, made it possible to obtain data of importance to further studies on this species in agroecosystems.

It was found that different crops situated in the group of cultivated fields are used to a different degree by the vole. Considerable densities occur in lucerne fields during periods when neighbouring potato or maize fields are not inhabited (Table 2). In crops usually settled by a vole population its pressure on plants varies markedly, depending on the phase in the cycle of variations in numbers of this species. With the most frequent course of this cycle, peak numbers occur every 4 years $(25 \%$ of the cycle's duration), with a year of minimum numbers $(25 \%$ a), while the remaining $50 \%$ of the time is taken up by years of moderate pressure from voles. During the study period the number of voles in an area of 2150 ha of cultivated fields in a year of low numbers was only $3 \%$ in relation to a year of high numbers $(100 \%)$, while the medium population numbers this figure was $23 \%$ (Table 3 ), and on this account basic estimates were calculated for the situation in the three phases of the population cycle.

The basic and initial value for further calculations is the estimate of the population's consumption. Annual consumption on an average hectare of crops was calculated on the basis of estimates of vole densities in crops and accepted estimates of amount of annual consumption per average hectare of crop (Table 14). During periods of high densities voles consume almost one ton of dry mass from an average hectare of lucerne, this being the maximum value found. In an average year consumption is from $2 \mathrm{~kg}$ dry mass/ha (spring crop) to $198 \mathrm{~kg}$ dry mass/ha (lucerne). A knowledge of the proportion of different crops in the structure of arable land made it possible to calculate the population's 11 - Acta Therioolgica 
consumption for the whole area of crops (Table 15). On 182 ha of lucerne voles consumed from 6 to 179 ton dry mass, on nearly 750 ha of winter cereals from 0.9 to 52 tons of dry mass/year. On the whole area of cultivated fields voles consumed from 7 to 247 tons of dry mass, and in years with average states of population numbers 58 tons dry mass/year (Table 15).

Table 14

Estimated yearly consumption by the common vole per hectare of crop (in kcal/ ha/year: g dry mass/ha/year).

\begin{tabular}{|c|c|c|c|c|c|c|}
\hline \multirow{2}{*}{ Crop } & \multicolumn{2}{|c|}{$\begin{array}{c}\text { Peak numbers } \\
(1971)\end{array}$} & \multicolumn{2}{|c|}{$\underset{(1973)}{\text { Minimum numbers }}$} & \multicolumn{2}{|c|}{$\begin{array}{c}\text { Average numbers } \\
(1972,1974)\end{array}$} \\
\hline & kcal & $\mathrm{g}$ & kcal & $\mathbf{g}$ & kcal & g \\
\hline Lucerne & $4,298,400$ & 976,909 & 152,505 & 34,600 & 874,650 & 198,784 \\
\hline Winter rape & 591,765 & 140,896 & 15,896 & 3,614 & 159,810 & 38,050 \\
\hline Winter cereal & 286,590 & 69,900 & 5,085 & 1,240 & 97,725 & 23,835 \\
\hline Spring crops & 51,590 & 12,582 & - & - & 10,110 & 2,466 \\
\hline $\begin{array}{l}\text { Root crops } \\
\text { and maize }\end{array}$ & - & - & 一 & - & - & - \\
\hline $\begin{array}{l}\text { Avg. ha of } \\
\text { cultivated field }\end{array}$ & 496,186 & 114,744 & 15,116 & 3,442 & 115,721 & 26,976 \\
\hline
\end{tabular}

Taible 15

Estimated consumption by a vole population in crop areas (in Mcal/ha/year : $t$ dry mass/year) ${ }^{1}$.

\begin{tabular}{|c|c|c|c|c|c|c|}
\hline \multirow[t]{2}{*}{ Crop } & \multicolumn{2}{|c|}{$\begin{array}{c}\text { Peak numbers } \\
(1971)\end{array}$} & \multicolumn{2}{|c|}{ Minimum numbers } & \multicolumn{2}{|c|}{$\begin{array}{l}\text { Average numbers } \\
(1972-1974)\end{array}$} \\
\hline & Mcal & $t$ & Mcal & $t$ & Mcal & \\
\hline Lucerne & 786.6 & 178.7 & 27.8 & 6.3 & 160.0 & 36.4 \\
\hline Winter rape & 38.4 & 9.1 & 0.9 & 0.2 & 10.4 & $2 . \overline{5}$ \\
\hline Winter cereal & 213.8 & 52.1 & 3.8 & 0.9 & 72.9 & 17.8 \\
\hline Spring crops & 28.0 & 6.8 & - & - & 5.5 & 1.3 \\
\hline $\begin{array}{l}\text { Consumption for } \\
\text { whole area of } \\
\text { cultivated fields }\end{array}$ & $1,066.8$ & 246.7 & 32.5 & 7.4 & 248.8 & 58.0 \\
\hline
\end{tabular}

1 Data on area of crops in study area in table 1.

On the basis of estimates of consumption and bioenergetic indices calculation was made of the amount of faeces and urine excreted by voles per hectare of different crops, with varying density these animals (Table 16). In a year of mass irruption, for an average hectare of lucerne the voles excreted over $180 \mathrm{~kg}$ faeces/ha/year, which counted together with the amount of urine voided, corresponds to excretion of about $39 \mathrm{~kg}$ pure nitrogen/ha (nitrogen contents in faeces and urine of $M$. arvalis according to Drożdż's data (1968). 
On the basis of the amount of biomass consumed (Table 14), after multiplying by the mean $M R: C$ indices contained in table 12 (ratio of biomass eliminated from further production to consumed biomass) estimates were obtained of the biomass of plants subjected to the vole's pressure (Tables 19,20). These values give a more accurate picture of the effect of these animals. The amount of biomass eliminated (cut down) by voles over the course of a year from the study area of fields is on an average four times greater than the biomass consumed (Table 15, 20).

Table 16

Amount of faces and urine excreted by voles per hectare of crop (in kcal/ha/ year : g dry mass/ha/year).

\begin{tabular}{|c|c|c|c|c|c|c|c|}
\hline \multirow[t]{2}{*}{ Crop } & & \multicolumn{2}{|c|}{$\begin{array}{c}\text { Peak numbers } \\
\text { (1971) }\end{array}$} & \multicolumn{2}{|c|}{$\begin{array}{c}\text { Minimum } \\
\text { numbers } \\
(1973)\end{array}$} & \multicolumn{2}{|c|}{$\begin{array}{c}\text { Average } \\
\text { numbers } \\
(1972-1974)\end{array}$} \\
\hline & & $\mathrm{kcal}$ & g & kcal & g & kcal & g \\
\hline Lucerne & $\begin{array}{l}\text { Faeces } \\
\text { Urine }\end{array}$ & $\begin{array}{l}803,801 \\
163,339\end{array}$ & 182,681 & $\begin{array}{r}28,518 \\
5,795\end{array}$ & $\begin{array}{l}6,481 \\
-\end{array}$ & $\begin{array}{r}163,559 \\
33,237\end{array}$ & 37,173 \\
\hline Winter rape & Faeces & 110,660 & 26,347 & 2,839 & 676 & 29,884 & 7,115 \\
\hline & Urine & 22,487 & - & 577 & - & 6,073 & - \\
\hline Spring crops & Faeces & 9,647 & 2,353 & - & - & 1,890 & 761 \\
\hline Avg. ha of & Urine & 1,960 & - & - & - & 384 & - \\
\hline $\begin{array}{l}\text { cultivated } \\
\text { fields }\end{array}$ & Faeces & 92,786 & 21,457 & 2,827 & 644 & 21,640 & 5,044 \\
\hline & Urine & 18,855 & - & 574 & - & 4,397 & - \\
\hline
\end{tabular}

1 Area of root crops and maize crop taken into account.

The vole eliminates an average of $109 \mathrm{~kg}$ dry mass (15-149 $\mathrm{kg}$ dry mass) from an average hectare. When densities are higher in lucerne crops the voles from the area of the crop eliminate nearly $80 \%$ of the biomass of plants eliminated from further production (Table 20). The remaining $20 \%$ is eliminated from the area of other crops, which jointly occupy $90 \%$ of the field area.

The relation between the biomass of consumed or eliminated plants and plarat production shows the extent to which the voles make use of the available food supply. In years of average numbers the vole consumes about $2.1 \%$ of the primary production of lucerne, $0.36 \%$ rape, $0.001-0.002 \%$ of cereals (Table 14). Consumption of primary production by voles on an average hectare of the group of cultivated fields (average primary production of the upper parts of plants $7222 \mathrm{~kg}$ dry mass/ha French et al., 1979) was from $0.04-1.6 \%$ (average $0.4 \%$ ). In a year of mass irruption on lucerne voles consume 179 ton dry mass $(10.4 \%$ of primary production) which corresponds to the entire crop from 19 ha of lucerne fields (Table 15). During this period the voles eliminate from 
Table 17

Estimate of rye and rape grain losses by means of analysis of intensity of damage to plants round vole colonies.

\begin{tabular}{|c|c|c|c|c|c|c|c|}
\hline \multirow{2}{*}{ 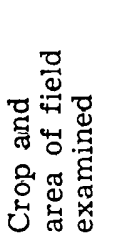 } & \multirow[b]{2}{*}{ 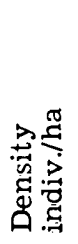 } & \multirow{2}{*}{ 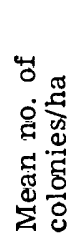 } & \multicolumn{2}{|c|}{$\begin{array}{c}\text { Mean area of plant } \\
\text { damage round } \\
\text { colonies }\end{array}$} & \multirow{2}{*}{ 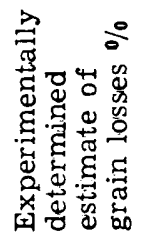 } & \multirow{2}{*}{ 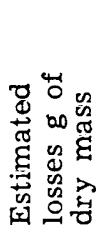 } & \multirow{2}{*}{ 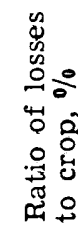 } \\
\hline & & & $\begin{array}{c}\text { Classes of } \\
\text { damage }\end{array}$ & $\begin{array}{c}\text { Area of } \\
\text { damaged } \\
\text { plants } \mathrm{m}^{2}\end{array}$ & & & \\
\hline $\begin{array}{l}\text { Rye } \\
(9 \text { ha) }\end{array}$ & 45 & 11 & $\begin{array}{r}1 \longmapsto 10 \\
11-50 \\
51 \longmapsto 75\end{array}$ & $\begin{array}{r}33 \\
8 \\
6\end{array}$ & $\begin{array}{l}10 \\
50 \\
80\end{array}$ & $\begin{array}{l}1175 \\
1424 \\
17110 \\
4309\end{array}$ & 0.13 \\
\hline $\begin{array}{l}\text { Rape } \\
(6.5 \text { ha })\end{array}$ & 80 & 18.3 & $\begin{array}{c}1-10 \\
11-33 \\
34-50 \\
51-100\end{array}$ & $\begin{array}{c}31 \\
14 \\
7 \\
4\end{array}$ & $\begin{array}{c}25 \\
45 \\
50 \\
50\end{array}$ & $\begin{array}{c}2371 \\
1932 \\
1070 \\
611 \\
5984\end{array}$ & 0.25 \\
\hline
\end{tabular}

Table 18

Estimated rye and rape grain losses based on percentage of grain in the composition of the vole's diet (calculated for quantitative estimates as in table 17).

Item

Density, individuals/ha

Period of feeding on grain, days

Amount of vole's consumption for period, kcal

Percentage of grain in diet

Amount of losses, $\mathrm{kcal} / \mathrm{ha}$

Caloric value of grain, $\mathrm{kcal} / \mathrm{g}$ dry mass

Amount of losses, $g$ of dry mass/ha

Ratio of losses to crop in $\%$
Rye

$\begin{array}{cc}45 & 80 \\ 30 & 30 \\ 20,250 & 36,000 \\ 10.1 & 8.3 \\ 2,045 & 2,988 \\ 4 & 5 \\ 511.3 & 597.6 \\ 0.014 & 0.025\end{array}$

further biomass production 786.5 tons of dry mass of lucerne, which constitutes the crop yield from nearly 84 ha of fields, that is, from about $46 \%$ of the area of this plant in the study area (Table 20). It was estimated that during a period of mass irruption in 1971 the voles eliminated $45.8 \%$ of plant biomass in the lucerne crops, which constituted the highest value found during the time these estimates were being arrived at (Table 21). Voles eliminate from 0.2 to $6.4 \%$ from an average hectare of crop and during a period of medium population numbers $1.5 \%$ of primary production. Use of the available weed biomass, judged 
on the basis of estimates of proportion in total consumption, is higher than for cultivated plants (Tables 9-11).

On the basis of analyses of the vole's diet, and experiments on the effect of damage to plants on their crop yield, an estimate was made of the extent of consumption of cereal grain and rape by the vole, and its influence on reducing the grain crop by consuming the green mass of plants. Although these data should be treated for the time being as

Table 19

Plant biomass eliminated from further production per hectare of crop (in kg dry mass/year).

\begin{tabular}{lccc} 
Crop & $\begin{array}{c}\text { Peak numbers } \\
(1971)\end{array}$ & $\begin{array}{c}\text { Minimum numbers } \\
(1973)\end{array}$ & $\begin{array}{c}\text { Mean numbers } \\
(1972,1974)\end{array}$ \\
\hline Lucerne & 4,298 & 152 & 875 \\
Winter rape & 366 & 9 & 99 \\
Winter cereal & 209 & 4 & 7.1 \\
Spring crops & 38 & - & 7 \\
\hline
\end{tabular}

Table 20

Plant biomass eliminated by voles from further production from area of cultivated fields (in $\mathrm{kg}$ dry mass/year).

\begin{tabular}{|c|c|c|c|c|}
\hline Crop & $\begin{array}{c}\text { Peak numbers } \\
\qquad(197,1)\end{array}$ & $\begin{array}{l}\text { Minimum } \\
\text { numbers } \\
(1973)\end{array}$ & $\begin{array}{l}\text { Mean numbers } \\
\quad(1972,1974)\end{array}$ & $\begin{array}{l}\text { Proportion of } \\
\text { biomass } \\
\text { eliminated } \\
\text { from crop to } \\
\text { that eliminated } \\
\text { from area of } \\
\text { crops in } \% 0^{1}\end{array}$ \\
\hline $\begin{array}{l}\text { Lucerne } \\
\text { Winter rape } \\
\text { Winter cereal } \\
\text { Spring crops } \\
\text { Whole area of crops } \\
(2150 \text { ha) } \\
\text { Mean ha of crops }\end{array}$ & $\begin{array}{r}746,534 \\
23,790 \\
155,914 \\
20,672 \\
\\
986,910 \\
459 \\
\end{array}$ & $\begin{array}{r}27,816 \\
586 \\
2,984 \\
- \\
31,385 \\
\square 15 \\
\end{array}$ & $\begin{array}{r}160,125 \\
6,435 \\
52,966 \\
3,808\end{array}$ & $\begin{array}{r}79.7 \\
2.4 \\
15.8 \\
2.0\end{array}$ \\
\hline
\end{tabular}

1 Data for year of peak numbers.

preliminary only, it may be said that with the densities found for the vole population in the study area, these are not values important to the economy. The estimated grain losses per hectare of crop did not exceed, even during periods of large population numbers, $0.5 \%$ of crop yield (Table 21). It was found that the vole, in eliminating the green mass of 
growing plants, causes ten times higher losses of grain crop (Table 17) than by directly consuming it (Table 18).

Table 21

Consumption by voles of the food supply of cultivated fields (in $\%$ of eliminated biomass in relation to crop of plants consumed/ha/year).

1 - Period of peak numbers (1971),

2 - Period of minimum numbers (1973),

3 - Mean numbers ( $\overline{\mathrm{x}}$ for 1972 and 1974),

\begin{tabular}{|c|c|c|c|c|c|c|c|c|}
\hline & \multicolumn{3}{|c|}{$\begin{array}{l}\text { Plants eliminated in } \mathrm{kg} \text { dry } \\
\text { mass/ha/year }\end{array}$} & \multicolumn{3}{|c|}{$\begin{array}{c}\text { Consumption of food } \\
\text { supply } \%\end{array}$} & \multicolumn{2}{|c|}{$\begin{array}{l}\text { Reduction in } \\
\text { crop, dry mass }\end{array}$} \\
\hline & Total & Grain & Weeds $^{1}$ & Total & Grain & Weeds $^{1}$ & $\mathrm{~kg} / \mathrm{ha}$ & $\%$ \\
\hline \multicolumn{9}{|c|}{ Lucerne } \\
\hline 1 & 4,298 & & 233 & 45.8 & & 31.9 & 4,298 & 45.8 \\
\hline 2 & 152 & - & 8 & 1.6 & - & 1.1 & 152 & 1.6 \\
\hline 3 & 875 & & 47 & 9.3 & & 6.4 & 875 & 1.6 \\
\hline \multicolumn{9}{|c|}{ Winter rape } \\
\hline 1 & 366 & 0.98 & 12 & 3.8 & 0.030 & 7.3 & 9.8 & 0.32 \\
\hline 2 & 9 & 0.04 & 0.3 & 0.1 & 0.001 & 0.2 & 0.4 & 0.01 \\
\hline 3 & 99 & 0.04 & 3 & 1.0 & 0.001 & 1.8 & 0.4 & 0.01 \\
\hline \multicolumn{9}{|c|}{ Winter cereal } \\
\hline 1 & 209 & 0.95 & 7 & 2.2 & 0.020 & 3.9 & 9.5 & 0.25 \\
\hline 2 & 4 & 0.03 & 0.1 & 0.04 & 0.001 & 0.1 & 0.3 & 0.01 \\
\hline 3 & 71 & 0.15 & 2 & 0.8 & 0.004 & 1.1 & 1.5 & 0.04 \\
\hline \multicolumn{9}{|c|}{ Spring crops } \\
\hline 1 & 3.8 & 0.90 & 1 & 0.5 & 0.024 & 0.5 & 9.0 & 0.24 \\
\hline 2 & - & 0.00 & 0.0 & 0.0 & 0.000 & 0.0 & 0.0 & 0.00 \\
\hline 3 & 7 & 0.17 & 0.2 & 0.1 & 0.001 & 0.1 & 1.7 & 0.01 \\
\hline \multicolumn{4}{|c|}{ Mean consumption of food } & 6.4 & & & & \\
\hline \multirow{2}{*}{\multicolumn{4}{|c|}{$\begin{array}{l}\text { supply per average hectare of } \\
\text { agriculture land in study area }\end{array}$}} & 0.2 & & & & \\
\hline & & & & 1.5 & & & & \\
\hline
\end{tabular}

1 Estimates only on basis of proportion in diet.

Table 22

Maximum losses caused by vole's activities in cultivated fields on Turew farm (State Farm Group, Czempin).

\begin{tabular}{|c|c|c|c|c|c|c|}
\hline 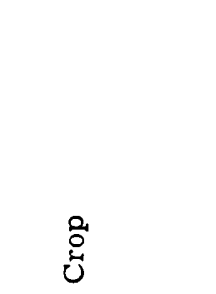 & 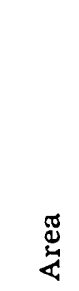 & 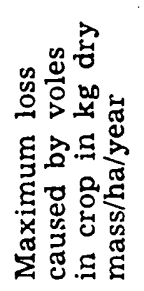 & 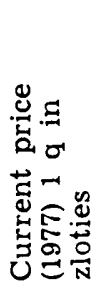 & 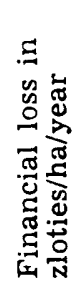 & 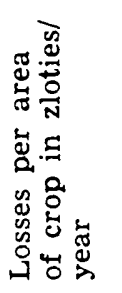 & 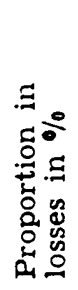 \\
\hline $\begin{array}{l}\text { Lucerne } \\
\text { Winter rape } \\
\text { Winter cereal } \\
\text { Spring crops } \\
\text { Total }\end{array}$ & $\begin{array}{r}115 \\
75 \\
152 \\
127\end{array}$ & $\begin{array}{r}4,298 \\
9.5 \\
9.8 \\
9.0\end{array}$ & $\begin{array}{r}150 \\
1,200 \\
500 \\
500\end{array}$ & $\begin{array}{r}6,447 \\
114 \\
49 \\
45\end{array}$ & $\begin{array}{r}741,405 \\
8,550 \\
7,448 \\
5,715 \\
763,118 \\
\end{array}$ & $\begin{array}{r}97.1 \\
1.1 \\
1.0 \\
0.8 \\
100.0 \\
\end{array}$ \\
\hline
\end{tabular}


An attempt was made at applying the data obtained on the vole population to an economic assessment of its activities. Thirty percent of the study area is occupied by land belonging to the Turew State Farm (State Farm Group, Czempin), which in respect of the results achieved is one of the leading national farms. Comparison was made of maximum estimates of the amount of losses caused by voles with areas of different crops on the farm, current prices for agricultural products and financial results of the farm (Table 22). The whole of the losses incurred amounted to $763,000 \mathrm{z}$, which in relation to the farm's income from plant production constitutes about $16 \%$. These are maximum data relating to the situation occurring every few years or so, on an average losses being about $3.5 \%$, and during periods of low population numbers of voles only $0.5 \%$ of income. Over $9.7 \%$ of financial losses is due to voles' activities in lucerne fields, while its presence in the area of annual crops is of no real economic importance.

\section{DISCUSSION}

The studies carried out over a period of several years permit of making a general estimate of the role of Microtus arialis in the group of cultivated field and also, although smaller in scale, the agrocenoses of the Wielkopolski region of Poland. This estimate was made possible by the application of a large number of reciprocally supplementing and controlling methods, defining the state of the vole population and also permitted of gaining a deeper insight into the mechanisms of its effect on vegetation. In these studies the relations, of fundamental importance for estimating the role of herbivores, between density and population occurrence structure, and the biomass of plants eliminated from further production, related to the primary production of the study habitats, were taken as a basis. Modification and interpretation of the results obtained were made possible by estimating the composition of the voles' diet and the regenerative capacity of plants. This sequence of relations would appear to be of the greatest importance, although the number of suggested interrelations, ways in which voles affect plants and their habitat continually increase and the studies proceed. Most often, however, there has up to the present been a lack of quantitative information on these connections.

At the very start of analysis of the results obtained the problem arises as to how far they are also representative of the greater part of Poland. It would appear that this depends chiefly on the typical 
character of the spatial structure of the study area, the densities of voles found and the way in which they occupy crops. The study area was intensively used for agricultural purposes, cultivated fields occupying $70 \%$ of the area, wooded land, meadows and land not cultivated agriculturally each occupying $10 \%$. This area structure is typical of the Kościan Plain area, considerable stretches of the Wielkopolski region (data from the WRN in Poznań) and the lowland part of Poland. During the study period there were two peaks of numbers of voles: in 1971 and 1975, and data were also available from the subsequent peak in 1978. As it was found that maximum numbers of rodents in years of their greatest effect vary only within limits of $30 \%$, the distribution and density occurring in the $1971-74$ cycle were taken as typical for the course of these phenomena in the study area. Similar results were obtained during this period for a number of districts in the central, southern and eastern part of the Wielkopolski region (data from the Plant Protection Institute in Poznań). Caboń-Raczyńska \& Ruprecht (1977), by means of analysis of owl pellets, consider the region in which the estimates were made as among areas with very high density of voles, occurring chiefly in the western and southwestern parts of Poland. The quantitative data given by Adamczewska-Andrzejewska (1974) show that the densities registered in the study area are similar to those occurring during this period in Lower Silesia and the Opole region, and are distinctly higher than the average for Pomerania, the Gdansk and Rzeszów districts. The occurrence of the vole in groups of cultivated fields in the study area is characterized by uneven settlement of the different crops. Lucerne, clover and grass plantations are very numerously inhabited; the vole occurs regularly but not in large numbers in cereal and rape crops, but clearly avoids maize, beet and potato crops. This kind of settlement is typical in Poland, Czechoslovakia (Kratochvil, 1959), Bulgaria (Straka, 1967) and many of the European regions of part of the Soviet Union (after data accumulated by Popov, 1960). It would seem that lucerne and similar crops are attractive to the vole for two reasons. In the first place these are the only fields in which the rodents' burrows are not destroyed by agrotechnical operations over a period of 3-4 years. In the second, lucerne forms a good food for the vole, as it has a high protein content (Sawicka-Kapusta et al., 1975), available throughout the year. In food tests lucerne was included in the group of plant species most readily consumed by the vole (Petrov, 1963). In tests of the attractiveness as food of 30 plant species for a closely-related species, Microtus pennsylvanicus (Thompson, 1965), it was found that it clearly prefers lucerne and two species of clover (Trifolium repens and T. pratense). 
The estimates presented in this paper relate to the group of cultivated fields in the study area $(69 \%$ of the area). As the vole also occurs here in meadows, edges of shelterbelts, and roads, on grass boundaries between fields and similar places, its numbers for the whole study area are higher than those shown in the paper. The area of these places is about 400 ha $(13 \%$ of the study area). Together with lucerne fields they constitute a place of shelter for the species during periods of low numbers. A similar situation occurs in the agrosystems of Bulgaria (Straka, 1967). Consequently, the numbers of voles in these habitats are usually greater than on the surfaces of open fields, even though quantitative data are so far scanty and not too reliable. The authors did not carry out their own absolute estimates there, as the method used for estimating number in these places is not very effective (the systems of burrows are too extensive). Meadows (10.2\% of the study area) form the greatest area of shelter places, and are consequently of greatest importance. The relative estimates made showed that they are (in addition to the wettest places) inhabited by the common vole, which is most often the dominant species there. The course taken by variations in numbers is the same as in lucerne fields, and the amount of primary production is also similar (Table 8). During the study period 12 quantitative estimates were also made on plantations of seed grasses and fields of mixed lucerne and grass, in which grasses dominated. It was found that the density of voles in areas in which lucerne grew in addition to grasses was slightly lower, although not different statistically from that occurring at the same time in lucerne crops, but in areas growing grass only the average figure is about $30 \%$ lower. If we accept that the average density of voles per average hectare of meadow and other shelter habitats is $33 \%$ lower than that occurring in lucerne fields, it is possible to calculate on the basis of estimates, assessments and field observations the total number of voles in the study area. In connection with the extensive area of meadows the estimated numbers of the vole population in shelter habitats would exceed, by even several percent, the numbers in the group of cultivated fields. Consequently the value for many estimates for the whole of the agrocenosis in the study area (population numbers, its consumption etc.) may be equal to about double the value obtained for the area of cultivated fields only, while corresponding mean values per average hectare of agrocenosis would increase by about $30 \%$.

The author had no quantitative estimates of the effect of the $M$. arvalis population on the group of crops at his disposal. The small number of estimates of the amount of consumption in relation to primary production apply almost entirely to lucerne crops. This value was estimated by 
Trojan (1969) as $0.8 \%$, in Spitz's studies (1968) with density of voles of $25-600$ individuals/ha of lucerne did not exceed $10 \%$, and Straka's data (1970) as $0.55-10.52 \%$. In the present study it was estimated as $0.4-10.4 \%$ (in years of average numbers $2.1 \%$ ). From $0.01-0.75 \%$ consumption of plant biomass was found for the winter cereals crops, while this figure was about twice higher in rape $-0.03-1.5 \%(0.4 \%)$. Trojan's estimate (1969) agrees with the value obtained in estimates for cereals, as he estimated consumption of primary production by voles in a rye field as $0.5 \%$.

It has been suggested for a long time that rodents and other herbivores often cause losses far higher than the amount they consume would appear to indicate. It is only in recent years, however, that papers have been published with quantitative estimates of these relations. Spitz (1968) calculated that the vole consumes only about $50 \%$ of the biomass of the lucerne shoots it bites off. Trojan (1969) estimates that losses in lucerne are three times greater than the amount actually consumed by voles. Straka (1970) found on an average a ratio of three to one in respect to consumption to losses in lucerne over the period of the fouryear cycle of variations in the numbers of voles. Zlotin \& Khodashova (1974) estimated that the biomass of primary production destroyed by voles in the steppes examined was 2.5 times greater than the amount consumed. Zlotin (1975) estimated that in meadows this ratio was 6-20 times. Tertil (1977) gives the ratio of losses to consumption as 4-12 times for lucerne during the period between the second and third mowing. Babińska-Werka (1979), who also estimated this index in lucerne, found that it varies within limits from 1 to as much as 17 times. The index estimated by the author's method did not vary within such wide limits $(1.9-7.0)$, and its mean value over the year was 4.4 , but when calculated in the same way from Babinska-Werka's estimates is higher i.e. 7.9. The direction of variations in the index is entirely in agreement - its low values in early spring and autumn, when the vole consumes chiefly young juicy lucerne shoots, and increasing values in periods of successive mowings, as the food value of plants diminishes (Sawicka-Kapusta et al., 1975) changes in the ratio of leaves to stalks (Spitz, 1968) etc. Estimates of this parameter obtained by the author of this paper, by Tertil (1977) and Babinska-Werka (1979), are difficult to compare at the present stage of studies, on account of the completely different methods used to obtain them, the calculations and conversions used, great differences between different series of experiments carried out in the same phases of plant's development. The discrepancies between estimates obtained by these authors became smaller, however, when 
averages are calculated for estimates. As an example - the coefficients obtained by Tertil (1977) during the period between the second and third mowings, although differing during the various series of experiments from 1.28 to 11.73 , have an average estimate of 4.8 , and this value in the author's estimates for the same period was 7.0, that is, these estimates for the same period do not differ in principle. It would seem that by means of the method proposed in this study it is often possible to obtain slightly under-estimated results, resulting from the way in which the voles' feeding are round the colonies was defined.

$M R: C$ ratio was estimated for the first time for rye and rape crops during the spring period. The values obtained are slightly lower than in the lucerne crop at this time. There are no estimates for these crops during a later period of development, since it is then difficult to carry them out by means of the method used. It may be assumed that the tendency observed is maintained, that is, the value of the index in the rape crop decreases even further, whereas in the rye crop, like lucerne, it will increase.

Several estimates have already been obtained for the whole of plant biomass eliminated by the vole from the area of the lucerne crop in relation to the primary production value of this plant. This value is usually considered identical with the estimate of losses caused by the vole. Since the authors of these data use different ways of estimating consumption, accepting different ratios of losses to consumption, and record different densities of voles in the fields examined, it is difficult to compare them. In the present study, depending on the population phase of the vole, they were estimated as 1.6 -45.8\% (average 9.3\%, with average numbers of voles). Higher values were obtained by Tertil (1977) for the period before the third mowing (when losses are the highest for the whole year) - 51\% and Babinska-Werka (1979), who estimated them on the basis of one-year studies in a number of fields, as on an average $8.7^{0} \%$ at the first mowing, to $60.2^{\%} \%$ at the third mowing.

The consumption of cereals and rape biomass by voles was estimated on the basis of the data collected. Unlike lucerne, in these crops the factor of most importance to man is the effect exerted by the vole on grain crop, which the vole affects by feeding on green parts. Hence the necessity for obtaining data on the composition of the vole's diet, periods of its increased harmfulness, estimates of the plants' capacity for regeneration. Plants react differently to the vole's nibbling activities. It was found that rape reacts unfavourably to nibbling from autumn to early spring, after which the vole practically ceases to be a pest in this crop. Cereals (results obtained similar to those of Tertil, 1977) do not react by a decrease in crop during the period of the early stages 
of its development (the plants regenerate the losses), but react very unfavourably during the period when ears forms and the plants flower. Kratochvil (1959) draws attention to the harmfulness of voles to winter cereals, both during the period following immediately on sowing, when voles consume the sown seed, obliging farmers to re-sow. No damage of this kind has been observed over the last 10 years $(1969-1979)$ in the study area. Lucerne reacts most strongly to damage done by voles in late summer, during the period from the second to third mowings, whereas in spring the vole's activities may even stimulate the growth of these plants. Similar results were also obtained by Babinska-Werka (1979). Spitz (1967) and Tahon (1969) found that these animals exerted a marked effect on crop yield during periods when the regeneration capacity of plants was low. They also emphasize that the animals' activities must take place at sufficiently early growing phases for the plant to have time for complete regeneration of losses. Ryszkowski et al. (1975) estimated that rye cut down by voles in March completely regenerate losses in grain and total biomass up to the harvesting period, but when harvested in May as greenstuff exhibit $43 \%$ deficiency of biomass oxi the vole's feeding areas in relation to control areas. Judenko (1967) also states that up to the time of harvesting, maize regenerated $70 \%$ of the losses incurred in spring due to rats feeding on it. The general conclusion arising from the data presented is that frequently it is not biomass eliminated by rodents itself, but the time of their activities which determines ecunomic results. It may be said that high population numbers of voles in summer are particularly harmful to lucerne crops, in May-June for cereals and for rape in autumn, winter and early spring.

Analysis of the vole's diet in the basic areas of crops in the study area showed that the proportion of green parts of plants in these animals' diet does not usually fall below $90 \%$, and very frequently is almost $100 \%$. The vole in fields feeds chiefly on the plants cultivated in the given field, and in certain phases of the development of these plants becomes to all intents and purposes a monophage. This estimate is confirmed by Straka (1967). Its diet becoming extremely simplified. It has been found that other kinds of food (seeds, parts of plants below ground, invertebrates) play a negligible part in its diet. Tendencies to such composition of the vole's diet was found during estimation of the food preferences of rodents (Petrov, 1963), but in relation to estimates of their diet in the case of voles caught in more diversified habitats, the proportion of these components in the diet of voles in fields is even lower (Sahno, 1957; Bashenina, 1962). Voles (as was found on all the study crops) by preference feed on weeds, which form a far higher 
proportion of its diet than in the biomass of plants in the crop. SawickaKapusta et al. (1975) explains this, after Prochaszka (1972) by the search for certain microelements which are missing from monotonous diets. Almost all the plant species encountered in the area covered by the vole's movements were consumed by these animals. This agrees with data given by a large number of authors, who drew up long lists of such species (e.g. Bashenina, 1962; Petrov, 1963). Voles failed to eat only $7 \%$ of the 68 species of green plants tested by Petrov (1963).

It was found that voles consume only a small proportion of cereal and rape grains in the crops examined. In Poland Skuratowicz (1957) has defined considerable losses in cereal crops as sporadic only, occurring under special conditions, whereas in the Ukraine, as stated by Sokur (1963), there are many examples of serious damage being done to wheat crops. Calculation was made from estimates of diet composition, and experiments intended to define the effect of these animals' feeding on crop yield, of the biomass of grain consumed and the ratios of values assessed in this iway in relation to crop yield. The data abtained point to minimum losses, below $5 \%$ of grain yield biomass, caused by voles in these crops. The estimate of reciprocal relations between grain losses caused by consumption itself and losses caused by the rodents' nibbling the green mass of plants produced an interesting result. It was found that grain losses due to plants being weakened by voles are ten times greater than losses caused by direct consumption of grain.

Stachyra (1975) compared Polish data on cereal crop losses caused by weeds, pathogens and pests (estimated in all as over $23 \%$, where the results of losses due to rodents may be less than $0.2 \%$ according to this author). It would therefore seem that in the very great majority of cases, even with population density many times greater than those found for the study area, losses caused by voles, will come below the so-called economic threshold of harmfulness. This concept defines such initial density of pest (or pathogen) occurrence which in developing may cause greater losses than the expense of plant protection operations (Stachyra, 1975). This is an important concept in plant protection, of considerable practical significance, but at the same time difficult to obtain. As has been partly shown in this paper, it cannot be a constart value, since it depends inter alia on the development phase of the plant its capacity for regeneration of damage, the way in which the plant is damaged by the pest and also the rate of increase of its density, the changes caused in the soil layer, composition of vegetation etc. At the same time it depends on the quality of agricultural management (crops, fertilization), since on the one hand strong plants are more resistant to the harmful effect of noxious factors, and on the other the costs of 
saving poor plantations may not be worthwhile when density of pests is smaller.

It is not the purpose of this study to discuss this problem in greater detail. Stachyra (1975) estimated that in Poland the vole may cause losses (from among plant species cultivated in the group of fields studies) in rye, wheat, potatoes, beet and lucerne, envisaging the carrying out of countermeasures in rye only. Estimates of the vole's activities show, however that in the study area (and probably in the greater part of Poland) it is chiefly a pest of perennial papilionaceous crops. So far no estimates have been prepared on the harmfulness threshold for voles in these crops. The preliminary recommendations available are based to too great a degree on estimates only and on forecasts, and not quantitative data. Spitz (1968) suggests that the harmful activities of voles begin when their density reaches about 200 individuals/ha of lucerne. Straka (1970) recommends that methcds to control voles should begin in early spring, when their density os about 100 individuals/ha ( $1-2$ active colonies/ $1000 \mathrm{~m}^{2}$ ). Sokur (1972), for Ukrainian conditions, considers that a density in spring of about 10 individuals/ha ( $4-5$ colonies/ha) constitutes a danger, and that the Soviet Ministry of Agriculture's recommendation for the steppe region, ordering that control action against voles should not begin until their numbers have reached a far higher level, is incorrect. On the strength of the author's own estimates, assuming that even $5 \%$ of eliminated lucerne biomass over the course of the year is already economically important, it may be calculated that this amount of biomass is eliminated by a vole population which in spring (April) occurs with a density of $30-40$ individuals/ha.

It would seem (as is understandable in view of the complex nature of this group of relations) that there is still a lack of reliable linking of estimates of the vole's role made by ecologists with the estimates of practical agriculturists. An example of this may be the data collected on the amount of lucerne crops obtained in state farms, which do not demonstrate the connection with variations in the density of voles in this area. Ecological estimates of their influence lose their actuality as a result of less accurate local measurements of the height of plants, of compensation for lost biomass by plants as the result of fertilization and other operations and, which would appear to be of great importance in these comparisons, of loss of part of the crop during the harvest due to the action of agricultural machinery. Clarification of the relation between these groups of estimates will certainly make an important contribution to estimating the role of $M$. arvalis and is one of the chief problems awaiting solution.

The next problem raised is more important from the aspect of increas- 
ing our knowledge than from a practical aspect. Spitz (1968), on the basis of suggestions made by Lamotte and Brulière, anticipates that herbivores take out as much from the system as they later return to it, that is, their activities are characterized by balance of profits and losses. He endoavours to calculate this, using the nitrogen balance as an example, showing that voles in lucerne may function as carriers of nitrogen substances. The data collected in this paper permit of developing these estimates to take a larger number of crops at different phases of the rodents' population cycle. For example, in lucerne voles consume an average of $23 \%$ of eliminated plant biomass. The remaining plant biomass decomposes in the field, in most cases during the same growing season - 75\% on the surface of the soil and abut $2 \%$ underground as material used for building nests. The consumed plant biomass remains almost entirely in the field in the form of solid and liquid excrements. If this is considered as a portion of nitrogen, it may be said that these are important values. For instance in years when voles occurred in large numbers per hectare of lucerne, they excreted about $39 \mathrm{~kg}$ of pure nitrogen in faeces, which forms the equivalent of $62-78 \%$ of the average portion of nitrogen which lucerne received during this period from mineral fertilization in the study area (data from the Rogaczewo Plant Breeding Station). 2.1\% of assimilated food is used for population production. This vole biomass partly returns to the soil as carrion. The greater part of $30.6 \%$ of vole biomass consumed in this area by the group of predators (Ryszkowski et al., 1973) reaches the shelterbelts and copses where predators have their hideouts, feed their young etc. This part of the consumed plant mass of the fields does not remain on it, and thus in the case of the vole this balance is not completely equilibrated in a given field, but only on the agrocenoses scale.

Contemporary intensive agriculture, aiming at maximum production, tends towards the simplest biological systems and the presence of the vole is undersirable to it. Attempts may be made at envisaging changes in the importance of $M$. arvalis as progress is made in agriculture. Golley et al. (1975) anticipates that small mammals will play a negligible role in intensively cultivated crops - the smallest role among all habitats of the temperate zone. Proof of this is supplied by the situation which currently exists in the highly cultivated fields of Belgium. The vole occurs there in very small numbers and regular cycles of fluctuations in numbers have gradually disappeared. Carefully planned and executed agricultural techniques, ploughing rapidity, harvesting rapidity and the ever more frequent absence of stacks etc. observed in fields in our times are of course causing a decrease in the numbers of voles, although it is still difficult to prove this quantitatively. With fewer 
papilionaceous crops, due to more maize, fodder and root crop plants, in a given region, the number of voles as it were automaticaly decline, that is, its possible periodically also to act through a change in the crop structure. The problem of losses caused by the vole is connected chiefly with modern agriculture, in which currently any and all possibilities of increasing crops are most important, and consequently this problem will gradually increase. There are now other methods for increasing crop yield - special agricultural techniques, control of water balance, fertilization, the quality of harvesting machines etc. which will achieve economic effects more rapidly than working out scientific methods for control of the vole. These problems will confront Polish agriculture in the future.

\section{REFERENCES}

1. Adamczewska-Andrzejewska K., 1974: Prognozowanie zmian zagęszczenia nornika polnego (Microtus arvalis Pall.) $\mathrm{w}$ oparciu o pogłębioną analize populacji. Biul. IOR, 57: 393-400.

2. Adamczewska-Andrzejewska K. \& Nabagło L., 1977: Demographic parameters and variations in numbers of the common vole. Acta theriol., 22: 431-457.

3. Babińska-Werka J., 1979: Effects of common vole on alfalfa crop. Acta theriol., 24, 22: $281-297$.

4. Bashenina N. V., 1962: Ekologia obyknovennoj polevki i nekotorye certy ee geografičeskoj izmenčivostii. Izd. Moskov. Univ.: 1-210. Moskva.

5. Caboń-Raczyńska K. \& Ruprecht A. L., 1977: Estimation of population density of the common vole in Poland: an analysis of owl pellets. Acta theriol., 22, 25: $349-354$.

6. Drożdż A., 1968: Digestibility and assimilation of natural foods in small rodents. Acta theriol., 13, 21: 367-389.

7. Drożdż A., Górecki A. \& Sawicka-Kapusta K., 1972: Bioenergetics of growtin of common voles. Acta theriol., 17, 18: 245-257.

8. Elton C., 1942: Voles, mice and lemming. Oxford Univ. Press: 1-496. London.

9. French N. R., Ryszkowski L., Titlyanova A. A. \& Zlotin R. I., 1979: Sravnenie struktury organičeskogo vešcestva v različnych ekosistemach. Izd. SC AN SSSR, biol. nauk. 2: 8-22.

10. Gębczyńska Z., 1976: Food habits of the bank vole and phenological phases of plants in an oak horbeam forest. Acta theriol., 21, 16: 223-236.

11. Golley L. B., Ryszkowski L. \& Sokur J. T., 1975: The role of small mammals in temperate forests, grasslands and cultivated fields. [In: "Small mammals their productivity and population dynamics", Eds. Golley F. B., Petrusewicz K., Ryszkowski L.]. Cambridge Univ. Press: 223-241. London.

12. Górecki A. \& Gębczyńska Z., 1962: Food conditions for small rodents in a deciduous forest. Acta theriol., 6, 10: 275-295.

13. Górecki A., 1965: Energy values of body in small mammals. Acta theriol., 10, 23: 333-352.

14. Grodziński W., Makomaska M., Tertil R. \& Weiner J., 1977: Bioenergetics and total impact of vole populations. Oikos, 29, 3: 494-510. 
15. Grulich I., 1959: Vlastni vypoðet skod v Ceskoslevensku. [In: "Hraboß polni Microtus arvalis", Ed. Kratochvil J.l. Ceskoslovenské Akademie Věd: 228-231. Praha.

16. Hanson L., 1970: Methods of morphological diet micro-analysis in rodents. Oikos, 21: 255-266.

17. Holišova V., 1966: Food of an overcrowded population of the bank vole Clethrionomys glareolus Schreb., in a lowland forest. Zool. listy, 15, 3: 207-224.

18. Ivlev W. S., 1953: Eksperimentalnaja ekologia pitania ryb. Piščepromizdat: 1-251. Moskva.

19. Judenko E., 1967: The loss of yield in a crop sweet corn (Zea mays L.) following the complete destruction of some plants at an early stage by brown rats (Rattus norvegicus) (Berk.). PANS 13, 4: 412-414.

20. Kratochvíl J., 1959: Hraboš polni Microtus arvalis. Ceskoslovenské Akademie Věd: 1-355. Praha.

21. Madany R., Radomski C., Eykowski B. \& Jakubiak J., 1972a: Warunki termiczne regionu poznańskiego ze szczególnym uwzględnieniem Turwi. Zesz. nauk. Inst. Ekol., 5: 35-74.

22. Madany R., Radomski C., Eykowski B. \& Jakubiak J., 1972b: Warunki opadowe rejonu Turwi. Zesz. nauk. Inst. Ekol., 5: 75-102.

23. Maksimov A. A., 1964: Selskohozjajstvennoe preobrazovanie landšafta i ekologija vrednych gryzunov. Izd. Nauka: 1-238. Moskva.

24. Margowski Z., 1972: Właściwości hydro-pedologiczne gleb okolic Turwi. Zesz. nauk. Inst. Ekol., 5: 109-136.

25. Martinet L., 1968: Cycle saisonnier de reproduction du campagnol des champs Microtus arvalis. Ann. Biol. anim. Biochem. Biophys., 7, 3: 245-259.

26. Migula P., 1969: Bioenergetics of pregnancy and lactation in European common vole. Acta theriol., 14, 13: 167-179.

27. Migula P., Grodziński W., Jasiński A. \& Musiałek B., 1970: Vole and mouse plagues in South-eastern Poland in the years 1945-1967. Acta theriol., 15, 16: $233-252$.

28. Petrov O. V., 1963: Pitanie myševidnyh gryzunov lesostepnych dubrav v laboratornyh uslovijah. Vopr. Ekol. Zivotn., 8: 119-174.

29. Petrusewicz K., 1967: Suggested list of more important concepts in productivity studies (definitions and symbols). [In: "Secondary productivity of terrestial ecosystems", Ed. Petrusewicz K.]. Pol. Sci. Publ. 1: 51-57. Warszawa.

30. Popov W. A., 1960: Mlekopitajuščie Volžsko-Kamskovo kraja. Ak. Nauk SSSR. 1-466. Kazan.

31. Prohászka K., 1972: Microelement content in lucerne hays. Acta Agron. Hung., 21, 1-2: 125-131.

32. Ružić A., 1967: Study of the effect of rodents (Rodentia) upon perennial artificial meadows. Arhiv. biol. Nauk, 19, 3-4: 147-167.

32. Ružic A., 1971: Harmful activity of the common vole Microtus arvalis Pall. on cereals during the fall and winter period. Zaštita Bilja, 22, 112-113: 65-76.

34. Ryszkowski L., 1975: The ecosystem role of small mammals. [In: "Biocontrol of rodents", Eds. Hanson L., Nilsson B.]. Ecol. Bull., 19: 139-145. Stockholm.

35. Ryszkowski L., Goszczyński J. \& Truszkowski J., 1973: Trophic relationships of the common vole in cultivated fields. Acta theriol., 18, 7: 125-165.

36. Ryszkowski L. \& Myllmäki A., 1975: Outbreaks of Microtus arvalis (Pall.) and other Microtinae rodents in central and east Europe. [In: "Biocontrol of rodents", Eds, Hanson L., Nilsson B.]. Ecol. Bull., 19: 57-64, Stockholm. 
37. Ryszkowski L. \& Petrusewicz K., 1967: Estimation of energy flow through small rodent population. [In: "Secondary productivity of terrestrial ecosystems". Ed. Petrusewicz K.]. Pol. Sci. Publ. 1: 125-146. Warszawa-Kraków.

38. Sahno I. I., 1957: Materiały $k$ izučenju sostava kormov nekotoryh myševidnyh gryzunov. Zool. Ž. 36, 7: 1084-1092.

39. Sawicka-Kapusta K., Dobrołęcka M., Drożdż A. \& Tertil R., 1975: Bioenergetic parameters of experimental groups of common voles (Microtus arvalis) (Pall. 1779)). Ekol. pol., 23, 2: 347-265.

40. Skuratowicz W., 1957: Uwagi o pojawach gryzoni polnych w Polsce w latach 1945-1955. Ekol. pol. B, 3, 1: 3-16.

41. Skuratowicz W., 1961: Gryzonie. Państw. Wyd. Rol. i Leśn. 1-115. Warszawa.

42. Sokur I. T., 1963: Skidlivi gryzuni i borot'ba s nimi. Wid. Ak. Nauk. Ukr. RCR. 1-94. Kiiv.

43. Spitz F., 1967: Etat actuel recherches on France sur le mechanisme et le determinisme des populations de Microtus arvalis. EPPO Publ., A, 41: 96-105.

44. Spitz F., 1968: Interactions entre la végétation épigée d’une luzerniére et des populations enclose ou non enclose de Microtus arvalis P. Terre et Vie, 3: 274-306.

45. Stachyra T., 1975: Ochrona roślin a ochrona przyrody. Państw. Wyd. Nauk. 1-426. Warszawa.

46. Straka F., 1967: Ekologia na obiknovenata polevka. Izd. Blgar. Akad. Nauk. 1-109. Sofija.

47. Straka F., 1970: Vzaimodejstvieto meždu ljucernovija posev i populacijata na obiknovenata polevka (Microtus arvalis Pall.). Rast. zašcita, 18, 3: 159-172.

48. Tahon J., 1969: Non related criteria between food consumption by small mammals and waste caused to vegetation. [In: "Energy flow through small mammal populations", eds. Petrusewicz K., Ryszkowski Liz]. Pol. Sci. Publ.: 159-165. Warszawa.

49. Tertil R., 1974: Wplyw żerowania nornika polnego (Microtus arvalis Pall.) na plonowanie pszenicy ozimej. Biul. IOR, 57: 385-391.

50. Tertil R., 1977: Impact of the common vole, Microtus arvalis (Pallas) on winter wheat and alfalfa crops. EPPO Bull. 7, 2: 217-339.

51. Thompson D. Q., 1965: Food preferences of the meadow vole (Microtus pennsylvanicus) in relation to habitat affinities. Amer. Midl. Nat., 74: 1: 76-86.

52. Trojan P., 1969: Energy flow through a population of Microtus arvalis (Pall.) in an agrocenosis during a period of mass occurrence. [In: "Energy flow through small mammal populations", Eds. Petrusewicz K., Ryszkowski L.]. Pol. Sci. Publ.: 267-279. Warszawa.

53. Trojan P. \& Wojciechowska B., 1969: Ecological model and tables of the daily costs of maintenance (DEB) of Microtus arvalis (Pall.). Ekol. pol. A, 17: 313-342.

54. Vinogradov B. S., Gromov I. M., 1952: Gryzuny fauny SSSR. Izd. Akad. Nauk SSSR. 1-296. Moskva-Leningrad.

55. Williams O., 1962: A technique for studying microtine food habits. J. Mammal., 43, 3: 365-368.

56. Zemanek M., 1972: Food and feeding habits of rodents in a deciduous forest. Acta theriol., 17, 23: $315-325$.

57. Zlotin R. I. \& Khodashova K. S., 1974: Rol' Životnych v biologičeskom krugovorote lesostepnych ekosystem. Izd. Nauka. 1-199. Moskva.

58. Zlotin R. I., 1975: Ocenka vozdejstva životnych - fitofagov na pervið̌nuju 
produkciju lugovo-stepičnovo pastvišća. [In: "Rol' životnych v funkcionirovanii ekosystem]. Izd. Nauka: 1-22. Moskva.

Accested, June 3, 1982.

\section{Janusz TRUSZKOWSKI}

\section{WPEYW NORNIKA ZWYCZAJNEGO NA ROSLINNOSC AGROEKOSYSTEMOW}

\section{Streszczenie}

Na obszarze 3100 ha typowego krajobrazu rolniczego Wielkopolski (Tabela 1) oceniono, w ciągu 6 kolejnych lat $(1971-1979)$ wpływ nornika zwyczajnego Microtus arvalis (Pallas, 1779) na plonowanie pól uprawnych. Analizowano zmiany zagęszczenia populacji nornika (Tabele 2,3), skład jego diety, zdolności regeneracyjne poszczególnych gatunków roślin (Tabela 4, Ryc. 1-5), średnią produkcję pierwotną części nadziemnych roślin uprawnych i chwastów, skład gatunkowy chwastów występujących na polach uprawnych (Tabele 5-7), udzial konsumpcji w całości biomasy usuniętych roślin (Tabele 12-14). Stwierdzono, że wysokie zagęszczenie może osiągać nornik jedynie na około $19 \%$ obszaru badań (lucerny, łąki, skraje zadrzewień), na około $48 \%$ występuje regularnie choć niezbyt licznie (głównie uprawy zbóż), zwykle nie zasiedla $23 \%$ obszaru (okopowe, kukurydza, lasy). Zdecydowanie najliczniej zasiedla uprawy lucerny. Na uprawie tej zajmującej 8,5\% całości areału upraw bytuje $74 \%$ obecnych na polach uprawnych norników. W okresie roku w zależności od fazy cyklu zmian liczebności norniki usuwają $z$ przeciętnego hektara lucerny od 1,6 do $45,8 \%$ biomasy produkcji pierwotnej (Tab. 21). Na pozostałych uprawach nie posiadają znaczenia gospodarczego usuwając jedynie przeciętnie około $1 \%$ produkcji pierwotnej (zboże ozime, rzepak) lub nawet $0.1 \%$ (zboża jare; Tabele 17, 18). $\mathrm{Z}$ przeciętnego hektara upraw na terenie badań populacja nornika usuwa $\mathrm{w}$ ciągu roku od 0,2 do $6,4 \%$ produkcji pierwotnej (Tabele 19-21). Skład diety nornika na obszarze pól cechuje małe zróżnicowanie. Zielone części roślin stanowią zwykle nie mniej niż $90 \%$ pożywienia. Udział niezielonych częścł roślin w diecie wynosi poniżej $10 \%$, pokarmu pochodzenia zwierzęcego poniżej $1 \%$. W okresach dojrzewania nasion roślin uprawnych stanowią one około $10 \%$ diety. Na wszystkich uprawach stwierdzono wybiórcze wykorzystywanie chwastów przez nornika. Tabele 9-11). Stwierdzono wybiórcze wyżerowywanie chwastów z powierzchni upraw. O wpływie nornika na wysokość plonu roślin uprawnych decyduje zagęszczenie oraz $\mathrm{w}$ dużym stopniu okres jego oddziaływania na roślinę, mniej natomiast sama wielkość usuniętej biomasy. Szkody powstają glównie w wyniku żerowania nornika na lucernie latem-jesienią, na zbożach późną wiosną-latem, na rzepaku od jesieni do późnej wiosny. W innych okresach następują silne odrosty roślin co $\mathrm{w}$ dużym stopniu rekompensuje straty wywołane przez pogryzy. Otrzymane oceny wysokości strat powodowanych przez nornika na uprawach w stosunku do dochodów z produkcji roślinnej miejscowych Państwowych Gospodarstw Rolnych wynoszą od 0,5 do $16 \%$ (w przeciętne lata $3,5 \%$ ). W tej wielkości aż $97 \%$ strat powoduje działalność populacji nornika na uprawach lucerny (Tabela 22). 